\title{
Eutrophication in a tropical pond: Understanding the bacterioplankton and phytoplankton dynamics during a vibriosis outbreak using flow cytometric analyses
}

\author{
R. Lucas ${ }^{a}$, C. Courties $^{b, c}$, A. Herbland ${ }^{a}$, P. Goulletquer ${ }^{d}$, A.L. Marteau ${ }^{e}$ and H. Lemonnier ${ }^{a,{ }^{*}}$
}

\author{
${ }^{a}$ IFREMER Département LEAD, BP 2059, 98846, Nouméa Cedex, New Caledonia \\ ${ }^{\mathrm{b}}$ UPMC UMS 2348, Observatoire Océanologique, F-66650, Banyuls/mer, France \\ ${ }^{c}$ CNRS, UMS 2348, Observatoire Océanologique, F-66650, Banyuls/mer, France \\ d IFREMER, Direction Prospective \& Stratégie Scientifique, rue de l'île d'Yeu, BP 21105, F-44311, \\ Nantes cedex 3, France

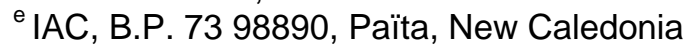

* Corresponding author : H. Lemonnier, Tel.: + 6873525 91; fax: + 6873511 77, email address :
Hugues.Lemonnier@ifremer.fr

\begin{abstract}
:
In tropical shrimp ponds, the increasing of feed input, concomitantly with the stocking shrimp biomass, induces an eutrophication of the ecosystem. Although difficult to maintain, its stability is required to guarantee the success of the culture. A 110-day period of phytoplankton and bacterioplankton stock and dynamics in an earthen pond (1.2 ha area, $1 \mathrm{~m}$ depth) was monitored using flow cytometry to provide baseline information on community characteristics and ecosystem instability. Seven autotrophic cell types were identified over the whole sampling period. Prokaryotic cells included Synechococcus sp., a group named UNK which presented an atypical new flow cytometric signature and picoeukaryotes (PEUK). Nanophytoplankton cells were represented by 4 groups: NAN1, NAN2, NAN3 and Cryptophytes. During the first part of the survey, picophytoplankton dominated the phytoplanktonic assemblage. The mean abundance of total cells (up to $8 \times 10^{6}$ cells $\mathrm{mL}^{-1}$ ) was among the highest recorded in marine and brackish waters. Bacterial abundance and production ranged from 0.8 to $5.1 \times 10^{7}$ cells $\mathrm{mL}^{-1}$ and from 30 to $110 \mu \mathrm{g} \mathrm{C} \mathrm{L}^{-1} \mathrm{~h}^{-1}$. A shift from pico to nanophytoplankton abundance was observed for a few days from d 96. During this period, heterotrophic bacteria production and abundance suddenly dropped, implying a change in the functioning of the microbial loop. This shift was concomitant with a significant shrimp mortality outbreak due to Vibrio penaeicida, the etiological agent of a disease known as Syndrome 93, which affects the shrimp industry in New Caledonia. This survey suggests that flow cytometric analysis could be used for the monitoring of aquaculture systems to improve our understanding of the complex phytoplankton and bacterial dynamics of these systems and its potential influence on disease development.
\end{abstract}

Keywords: Tropical shrimp aquaculture; Ecosystem shift; Phytoplankton; Bacterioplankton; Vibrio; Flow cytometry 


\section{Introduction}

During an aquaculture production cycle, feed supply in shrimp ponds increases concomitantly with the stocking biomass, which can induce an increasing eutrophication level in the pond ecosystem (Burford et al., 2003a). Subsequently there is an increase in algal biomass, whereas phytoplankton communities are characterized by a continuous succession of dominant species due to dynamic changes of growth factors such as light, temperature and nutrient concentrations (Burford, 1997; Yusoff et al., 2002; Casé et al., 2008). Phytoplankton communities are primary producers and consumers of dissolved oxygen and maintaining the stability in the stocking biomass and metabolic activity of phytoplankton communities is essential to provide a suitable environment for cultured animals. Changes in the phytoplankton community due to the increase in nutrients may result in outbreaks of harmful algal blooms (Cloern, 2001; Alonso-Rodriguez and Paez-Osuna, 2003; Zimba et al., 2006). Bacteria populations also rapidly respond to physical, chemical and biological changes in eutrophying systems. This issue is of particular interest when endemic and pathogenic bacterial populations, such as certain Vibrio, may pose a health risk to reared populations (Moriarty, 1997).

In New Caledonia, the grow-out shrimp industry is affected by two vibriosis. One is known as "Summer syndrome" and is caused by Vibrio nigripulchritudo. The other, known as “Syndrome 93”, results in high shrimp mortality during the transition periods between the two main seasons (Mermoud et al., 1998). Epidemiological and bacteriological studies revealed that moribund shrimp always suffered from severe bacterial septicaemia due to $V$. penaeicida (Costa et al., 1998; Goarant et al., 1999; Saulnier et al., 2000). This pathogen demonstrated high pathogeneicity and is considered by several authors (Saulnier et al., 2000; Goarant and Merien, 2006) as a specific rather than opportunistic agent, in contrast to many other Vibrio 
species that produce disease only in stressed shrimp. Vibrio penaeicida is frequently detected in water pumped from the bays, and might therefore be an infection source for grow-out ponds (Goarant et al., 1999; Goarant and Merien, 2006). Stocking shrimp density is the main risk factor, so, an increase of the density from 15 to 40 shrimp $\mathrm{m}^{-2}$ was shown to grow the probabilities of the appearance and the severity of the epizooty in the ponds (Lemonnier, 2007). The highest mortalities occurred in ponds following sudden temperature drops (Mermoud et al., 1998) and might be related to eutrophication intensity (Lefevre et al., 2004). However, our knowledge of the dynamics of the ecosystem and its relationship to the epizooty is very limited.

One of the problems in describing and understanding disease development in aquaculture grow-out ponds is the monitoring of the microbial communities. Time series observations are critical to assess the direct and indirect effects resulting from the microbial population dynamics (Li, 2009). Flow cytometry (FCM) has emerged as a powerful analytical tool that allows fast access to cell numbers or densities, cytometric biomasses, and size classes as well as enabling diversity assessment within a biological community. Flow cytometry facilitates the processing of a large number of samples and microbial population monitoring over wide temporal scales, revealing the heterogeneity present in the populations or communities. This technique is now communally used in oceanography from 25 years to study phytoplankton and bacterioplankton (Troussellier et al., 1993; Legendre et al., 2001). However, FCM application in ecological studies dealing with marine eutrophic aquaculture system remains very infrequent (Endo et al., 2000). Although flow cytometry does not provide "taxonomic information”, it can specify sub-groups based upon flow cytometric parameters such as fluorescence and relative side scatter. For phytoplankton species, flow cytometry can distinguish community structure at very broad phylogenetic resolution, for instance by 
separating Synechococcus sp., Prochlorococcus sp. and picoeukaryotes within the picophytoplankton compartment (Legendre et al., 2001). This technique is also regularly used to discriminate sub-populations in the heterotrophic bacterial community within natural marine communities through the nucleic acid content and cell scattering properties of individual cells (Troussellier et al., 1995; Marie et al., 1997). It is well established that heterotrophic bacteria are important in the structure and dynamics of marine food webs and biogeochemical cycles (Cole et al., 1988). At least 2 subpopulations of bacterial cells, High Nucleic Acid content (HNA) and Low Nucleic Acid content (LNA) bacteria, can be discriminated. The findings of several studies have supported the idea that HNA bacteria can be considered as the most active component of marine bacterioplankton assemblage (Gasol et al., 1999; Lebaron et al., 2001a; Morán et al., 2007). This discrimination is an important step towards the identification of the most important micro-organism groups and their functions inside the whole community (Lebaron et al., 1999; Lebaron et al., 2001b; Schäfer et al., 2001). The correlation among bacterial variables and other biological variables could help to understand which factors control bacterial dynamics in the pond ecosystem (Andrade et al., 2003).

In this study, eutrophication of the pond ecosystem was investigated by characterizing pond conditions during a shrimp grow-out period using high frequency FCM measurements concomitantly with traditional environmental monitoring (i.e. oxygen concentrations, Chlorophyll a survey). Moreover, the overall flux of bacterial production was evaluated as an index of available organic matter for bacteria, in order to characterize the trophic status (Ducklow and Carlson, 1992). Besides providing a baseline information of community characteristics and ecosystem variability associated to vibrioses, our study aims to assess the 
use of flow cytometry technique as a tool to improve the process understanding and early detection of unbalanced ecosystem for further pond management.

\section{Materials and Methods}

\subsection{Field survey}

The field survey was conducted over a 4-month period in 2004 in a 1,200 $\mathrm{m}^{2}$ pond at the Saint-Vincent (IFREMER) aquaculture research centre, located on the West Coast of New Caledonia (South Western Pacific-2155’36 S, 16605’04 E). The pond was dried out 82 days before filling. Ten days later, at day 0 (d 0), the pond was stocked with Litopenaeus stylirostris post-larvae PL20 at an initial stocking density of 19 shrimp $\mathrm{m}^{-2}$. For the whole duration of the survey, shrimp were fed on a daily basis with a commercial feed having a 3540\% protein concentration using usual feeding strategy described by Della Patrona and Brun (2008). The fed input increased from $0.5 \mathrm{~g} \mathrm{~m}^{-2}$ at the beginning to about $6.0 \mathrm{~g} \mathrm{~m}^{-2}$ at $\mathrm{d} 60$ and stabilized after that until the end of the survey. Fertilization was carried out by adding a total amount of $70 \mathrm{~kg}$ of urea starting six days before the post-larvae deployment and lasting 41 days. Daily water exchange in the pond varied from $5 \%$ to $20 \%$ of the total pond volume depending on the shrimp biomass, calculated from shrimp weight and estimated survival rate (Della Patrona and Brun, 2008). From d 91 to d 119, oxygen levels were maintained by

mechanical aeration (total power applied: $3.4 \mathrm{hp} \mathrm{ha}^{-1}$ ). During the rearing, shrimp mortality was estimated by counting dead and moribund shrimp at the pond edges. At d 119, all the shrimp were harvested including buried shrimp to calculate the final survival. 


\subsection{Sampling and field data}

Pond water samples were collected at 07:00 am and 4:00 pm every seven days from d 0 (beginning of the rearing) until d 41, and every two days from d 41 to $d 119$ (end of the rearing). Samples were collected at three stations: in the middle of the pond, near to the discharge gate and at the opposite end from the discharge gate. At each station, samples were collected from two depths: sub-surface samples were collected from $15 \mathrm{~cm}$ below the water surface and bottom samples from $5 \mathrm{~cm}$ above the sediment. For sub-surface samples, water was collected by opening and closing a submerged $2 \mathrm{~L}$ polyethylene bottle. Bottom subsamples (5 cm above sediment) were pumped (manual pump) into a 2-L polyethylene bottle through silicone tubing, avoiding sediment disturbance. Dissolved oxygen (DO), pH and salinity were recorded in situ at each station (bottom and surface) with portable oxygen (WTW Oxi 315i), pH (WTW pH 340i) and conductivity (WTW Cond 315i) meters. Temperature was automatically and continuously (30-minute steps) recorded using three optic StowAway Temp Loggers (Aquatic Eco-systems, USA) deployed at the three stations close to the pond bottom. Input water samples were collected in the morning every seven days in the first part of the survey and every two days from d 41 to $d 119$. Daily rainfall data were obtained from the local Weather Forecast Service (Météo-France, Nouméa).

\subsection{Laboratory analysis}

The following parameters were analyzed on pond water samples (surface and bottom) collected near the discharge gate only at 07:00 am and in the input water: nitrate and nitrite $\left(\mathrm{N}_{\mathrm{ox}}\right)$, silicates $(\mathrm{Si})$, size fractioned chlorophyll $a(\mathrm{Chl} a)$ and bacterial production (BP). Flow cytometry measurements were conducted on all samples collected at 07:00 am. 
Nutrient analysis: Prior to nutrient analysis, water samples (500 mL) were immediately filtered through a GF/F (nominal pore size $0.45 \mu \mathrm{m}$ ) Whatman filter. Colorimetric analyses for total ammonia nitrogen $\left[\mathrm{NH}_{4}{ }^{+}+\mathrm{NH}_{3}\right.$ )-N] (TAN), dissolved inorganic phosphorus (DIP) and silicates (Si) were carried out on fresh samples on a Spectronic Genesis 5 spectrophotometer (Thermo Electron Corporation) equipped with a $10 \mathrm{~cm}$ cell. TAN was measured using methods described by Koroleff (1976) and DIP according to the molybdenum blue reaction (Murphy and Riley, 1962). Concentrations are expressed in $\mu \mathrm{mol} \mathrm{N} \mathrm{L}{ }^{-1}$ and in $\mu$ mol $\mathrm{P} \mathrm{L}^{-1}$ for TAN and DIP, respectively. Silicates were analyzed on thawed samples as previously described (Mullin and Riley, 1955). Nitrate and nitrite $\left.\left[\mathrm{NO}_{2}{ }^{-}+\mathrm{NO}_{3}{ }^{-}\right)-\mathrm{N}\right]\left(\mathrm{N}_{\mathrm{ox}}\right)$ were determined on thawed samples using standard colorimetric techniques on a Bran+Luebbe AutoAnalyzer III system (Raimbault et al., 1990).

Chlorophyll a (Chl a): 25 to $50 \mathrm{~mL}$ water samples were filtered through Whatman GF/F filters. Filters were stored frozen prior to analysis. Chl $a$ and Pheophytin $a$ concentrations were determined using a fluorometer (Model TD700, Turner designs, Sunnyvale, CA, USA) according to the method described by Holm-Hansen et al. (1965). The size fractioned Chl $a$ (< $2 \mu \mathrm{m}$; 2 to $20 \mu \mathrm{m}$; and $>20 \mu \mathrm{m}$ ) were determined on subsamples, using $2 \mu \mathrm{m}$ Nucleopore membranes and $20 \mu \mathrm{m}$ nylon sieves.

Flow cytometry (FCM): Sub-samples $(2 \mathrm{~mL}$ ) were preserved with $1 \%$ glutaraldehyde (final concentration) and stored in liquid nitrogen pending FCM analysis applied to phytoplankton and bacteria populations (Vaulot et al., 1989). Samples were defrosted at room temperature and subsequently analyzed using a FACSCan flow cytometer (BD-Biosciences) equipped with an air-cooled argon laser (488 nm, $15 \mathrm{~mW}$ ). Fluorescent $1.002 \mu \mathrm{m}$ beads (Polysciences Inc., Europe) were added to each sample as an internal standard to normalize cell properties 
and to compare cell populations. Accurate analyzed volumes and subsequent estimations of cell concentrations were calculated by measuring the remaining volume and subtracting it from the initial subsample volume $(1 \mathrm{~mL})$. Phytoplankton cells were discriminated and enumerated according to their right-angle light scattering properties (SSC, roughly related to cell size) and orange (560-620 nm) and red (> $670 \mathrm{~nm}$ ) fluorescence due to phycoerythrin and chlorophyll pigments, respectively. After thawing samples for bacterial counts, $1 \mathrm{~mL}$ subsamples were incubated with the nucleic acid stain SYBRGreen I (Molecular Probes) for 15 minutes at room temperature in the dark (Marie et al., 1997). Total bacterial cells (TBA) were enumerated and two clusters (i.e. High Nucleic Acid content (HNA) and Low Nucleic Acid content (LNA) bacteria) were differentiated according to the variations of light scatter properties (relative cell size) and green fluorescence related to nucleic acid content.

Bacterial production (BP) was determined from $\left[{ }^{3} \mathrm{H}\right]$-thymidine incorporation rates (Smith and Azam, 1992). Triplicates of $1 \mathrm{~mL}$ seawater samples were incubated in the dark at in situ temperature for 30 min with $\left[{ }^{3} \mathrm{H}\right]$-thymidine (final concentration $15 \mathrm{nM}, 1.8 \mathrm{TBq} \mathrm{mmol}^{-1}$, Amersham). Concomitantly, a sample used as control was killed with $150 \mu \mathrm{L}$ trichloroacetic acid (TCA) 50\%. Except for the control sample, bacterial production was stopped by adding $150 \mu \mathrm{L}$ TCA $50 \%$. After precipitation at $2{ }^{\circ} \mathrm{C}$ for $15 \mathrm{~min}$, labelled material was collected by centrifugation (10 min at 13,000G). The pellet was rinsed 3 times with $1 \mathrm{~mL}$ of ice-cold TCA $5 \%$ and samples were stored at $-20^{\circ} \mathrm{C}$ until radioactivity determination. Scintillation counting was carried out using a TriCarb 1600 TR after addition of $1 \mathrm{~mL}$ of scintillating liquid (Ultima Gold MV) and taking into account quenching correction. The mean coefficient of variation for triplicate determinations was $8 \%$. Biomass production rates were computed using the average of empirically determined conversion factor of $2.91 \times 10^{18}$ cells $\mathrm{mol}^{-1}$ of thymidine (Briand et al., 2004). Bacterial carbon production was calculated using a conversion factor of 30.2 fg C.cell $^{-1}$ (Fukuda et al., 1998). 


\subsection{Statistical analysis}

Linear correlations among parameters were performed using permutation tests. Data were normalized using $\log (x+1)$ transformation, and averaged by week to account for serial correlation. The significance threshold was set to $\mathrm{p}=0.01$ and 0.05 . We used the S-plus statistical software (TIBCO Software Inc., Sommervile, MA, USA).

\section{Results}

\subsection{Shrimp mortality}

A significant mortality outbreak due to $V$. penaeicida was observed from d 97 to the end of the survey (Fig. 1). The highest mortality occurred at $d 100$. Final shrimp survival was $44 \%$. In this survey, the mortality level linked to the vibriosis outbreak by itself could not be estimated.

\subsection{Rainfall and physico-chemical parameters}

The sampling period started at the end of the austral summer (11 February 2004), a period characterized by heavy rainfall. Rain fell at an almost continuous rate of $70.7 \mathrm{~mm}$ per day between $\mathrm{d} 37$ to $\mathrm{d} 47$. A second intense precipitation event (76 $\mathrm{mm} \mathrm{d}^{-1}$ ) occurred during the study period at d 89. During the survey, salinity ranged from 31 to $36 \mathrm{ppt}$. During each rain period, a 3 unit salinity decrease in the pond was observed. Seawater temperature decreased steadily from $35^{\circ} \mathrm{C}$ to $20^{\circ} \mathrm{C}$ over the course of the study period (Fig 1). Dissolved oxygen concentrations decreased from 9 to $2 \mathrm{mg} \mathrm{L}^{-1}$ between d 0 to d 90 . From d 91, after the introduction of mechanical aerators, oxygen concentrations ranged between 4.2 to $5.6 \mathrm{mg} \mathrm{L}^{-1}$. From d 0 to d 90, $\mathrm{pH}$ measurements were higher than 8.5 , decreasing to 7.8 at $\mathrm{d} 90$. From d 92, $\mathrm{pH}$ increased steadily, reaching 8.2 at the end of the survey. 


\subsection{Nutrients}

Between d 0 and d 90, daily mean TAN and DIP concentrations in the pond $(\mathrm{N}=6)$ were less than $0.8 \mu \mathrm{mol} \mathrm{L}^{-1}$ and $0.1 \mu \mathrm{mol} \mathrm{L}{ }^{-1}$, respectively. At d 91, TAN and DIP concentrations temporarily increased to $7.9 \mu \mathrm{mol} \mathrm{L}{ }^{-1}$ (range 5.2 - 9.6) and $0.7 \mu \mathrm{mol} \mathrm{L} \mathrm{L}^{-1}$ (range 0.23 - 1.51), respectively (Fig. 2a, 2b). From d 96 onwards, daily mean concentrations were less than 1.6

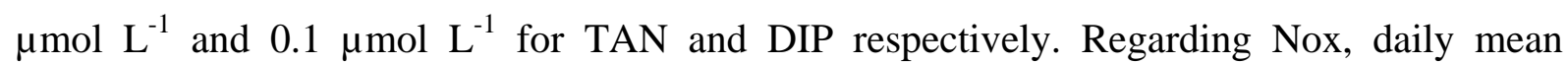
concentrations were below $0.5 \mu \mathrm{mol} \mathrm{L}{ }^{-1}$, except at d 14 and d 91 - d 93, when concentrations reached 1.75 and $1.32 \mu \mathrm{mol} \mathrm{L}{ }^{-1}$ respectively. Concentrations of TAN and DIP were spatially homogenous during the survey, so silicate measurement at one station is assumed to be representative of the pond's water column. Mean concentrations in the pond $(\mathrm{N}=28)$ and in the input water $(\mathrm{N}=20)$ were 15.8 and $24.2 \mu \mathrm{mol} \mathrm{L} \mathrm{L}^{-1}$ respectively. Concentrations of silicates in the pond (Fig. 2c) were at their lowest level at the beginning of the survey $\left(12.1 \mu \mathrm{mol} \mathrm{L}{ }^{-1}\right)$, around d $65\left(4.8 \mu \mathrm{mol} \mathrm{L}{ }^{-1}\right)$ and d $98\left(3.1 \mu \mathrm{mol} \mathrm{L}{ }^{-1}\right)$.

\subsection{Phytoplankton}

\subsubsection{Total and size-fractionated chlorophyll $a$ biomass}

Total Chl $a$ biomass increased steadily during the studied period (Fig. 3) from $20 \mu \mathrm{g} \mathrm{L}^{-1}$ to 71 $\mu \mathrm{g} \mathrm{L}{ }^{-1}$. Size-fractionated biomass was dominated by the $<2 \mu \mathrm{m}$ fraction during the early part of the survey ( $\mathrm{d} 0$ to $\mathrm{d}$ 77) (Fig. 4). The 2-20 $\mu \mathrm{m}$ fraction became significant from $\mathrm{d} 82$ to the end. Before then, the concentration of this fraction was below $20 \mu \mathrm{g} \mathrm{L}^{-1}$. The $>20 \mu \mathrm{m}$ fraction represented on average less than $15 \%$ of the total Chl $a$ biomass. One important observation was the disappearance of the $<2 \mu \mathrm{m} \mathrm{Chl} a$ fraction at the end of the rearing, and its replacement by the 2-20 $\mu \mathrm{m}$ upper Chl $a$ fraction . In the inlet channel, the mean total Chl $a$ concentration was $2.62 \pm 2.19 \mu \mathrm{g} \mathrm{L}^{-1}$ (Fig. 3). The 2-20 $\mu \mathrm{m}$ fraction dominated $66 \%$ of the 
samples. Chl $a$ mean biomass in fraction $<2 \mu \mathrm{m}$ and $>20 \mu \mathrm{m}$ represented $22 \%$ and $23 \%$ of the total Chl $a$, respectively.

\subsubsection{Description of cytometric diversity}

Using FCM, seven main cell types were detected during the sampling period, with no difference between the surface and bottom layers. They were identified as: SYN, UNK, PEUK, NAN1, NAN2, NAN3 and CRY (Fig. 5).

The UNK, SYN and PEUK signatures belong to the picoplankton size class, passing through a $3 \mu \mathrm{m}$ Nuclepore filter (data not shown), while the others were considered as nanoplanktonic cells.

- UNK (for unknown cells) presented an atypical new flow cytometric signature characterized by the lowest red fluorescence (FLR/1 $\mu \mathrm{m})$ and SSC/1 $\mu \mathrm{m}$ properties situated between those of SYN and PEUK.

- SYN showed a low normalized FLR associated with the lowest normalized SSC and a high orange fluorescence due to phycoerythrin content (data not shown), characterizing this signature as belonging to the marine cyanobacteria Synechococcus sp.

- PEUK presented a flow cytometric signature characteristic of pico-autotrophic eukaryotes whose cell properties vary, spreading mainly within the second SSC/1 $\mu$ m-decade during the whole sampling period.

- NAN1, NAN2 and NAN3 signatures corresponded to different nanoplanktonic populations, showing an increasing relationship between their normalized SSC and FLR properties, which could be related to their cell size and chlorophyll content increase above $3 \mu \mathrm{m}$.

- The CRY signature was characteristic of to cells emitting orange (data not shown) and red fluorescence due to biliprotein and chlorophyll pigments, respectively. On the basis of their 
apparently large cell size $(\mathrm{SSC} / 1 \mu \mathrm{m})$ and fluorescence properties, they may belong to Cryptophytes.

\subsubsection{Temporal variations of cytometric groups}

Surface and bottom picophytoplankton abundance were very similar within the pond water column, indicating an absence of stratification (results not shown). Picophytoplankton dominated the phytoplankton community (>90\%) with the exception of d 96 and $\mathrm{d} 98$. For the 3 picophytoplankton cell types (SYN, UNK, PEUK), exceptionally high and frequent abundances were found, up to $1 \times 10^{6}$ cells $\mathrm{mL}^{-1}$.

- UNK (Fig. 6a) was the dominant population of the picophytoplanktonic community and represented 53\% of the cells enumerated during the survey. UNK cells showed several peaks at $\mathrm{d} 41\left(3.5 \times 10^{6}\right.$ cells $\left.\mathrm{mL}^{-1}\right), \mathrm{d} 70\left(5 \times 10^{6}\right.$ cells $\left.\mathrm{mL}^{-1}\right), \mathrm{d} 82\left(3 \times 10^{6}\right.$ cells $\left.\mathrm{mL}^{-1}\right)$ and $\mathrm{d} 107$ $\left(2.5 \times 10^{6}\right.$ cells $\left.\mathrm{mL}^{-1}\right)$. The lowest abundances were observed at d $96\left(1 \times 10^{5}\right.$ cells $\left.\mathrm{mL}^{-1}\right)$.

- SYN (Fig. 6b) and UNK showed similar trends. However, abundances were generally lower for UNK.

- PEUK (Fig. 6c) abundance showed the same pattern, although it was characterized by an enhanced variability between d 25 to d 90 . Values were lower than for the UNK and SYN groups and reached a maximum of $2.6 \times 10^{6}$ cells $\mathrm{mL}^{-1}$ at $\mathrm{d} 70$ and decreased from $\mathrm{d} 91$ to $\mathrm{d}$ 96.

As described above for picophytoplankton, nanophytoplankton abundances were generally comparable at the surface and bottom layers (data not shown). For nanophytoplankton, the main observed feature was the development of NAN1, NAN2, NAN3 cells when picophytoplankton (SYN, UNK and PEUK) had their lowest densities within the sampling period, from d 0 to d 20 and from d 96 to d 102. 
- The NAN1 population (Fig. 6d) dominated the nanophytoplankton group. Abundances fluctuated around $2.5 \times 10^{4}$ cells $\mathrm{mL}^{-1}$ during the first 3 weeks, then dropped, and peaked around $2.2 \times 10^{5}$ cells.mL $\mathrm{m}^{-1}$ at $\mathrm{d}$ 96. This peak was observed for 3 successive days and then abundances decreased until the end of the survey.

- NAN2 population (Fig. 6e). Except at the beginning of the survey and until d 96, NAN2 abundance was low, generally below $3.5 \times 10^{3}$ cells $\mathrm{mL}^{-1}$. As observed for NAN1, the growth of NAN2 occurred clearly after d 96, reaching values close to $2 \times 10^{4}$ cells $\mathrm{mL}^{-1}$, when picophytoplankton concentrations reached the lowest values.

- NAN3 population (Fig. 6f). According to their SSC and FLR properties, NAN3 cell type is presumed to correspond to the highest cell size of nanophytoplanktonic species detected in the pond water. Three peaks in abundance were observed during the survey. One of $1.2 \times 10^{4}$ cells $\mathrm{mL}^{-1}$ was centred on $\mathrm{d} 8$, a second on $\mathrm{d} 58$ and the third on $\mathrm{d} 100$ with abundance around $4 \times 10^{3}$ cells $\mathrm{mL}^{-1}$.

- CRY cells were sporadically represented with abundance below $1.3 \times 10^{4}$ cells $\mathrm{mL}^{-1}$ (data not shown).

Abundance of the different cytometric groups in the inlet channel was lower than in the pond. SYN, UNK and PEUK were lower than $40 \times 10^{5}, 6 \times 10^{5}$ and $1 \times 10^{5}$ cells $\mathrm{mL}^{-1}$ respectively, and cell abundance was characterized by non-systematic variability. Abundance of NAN1, NAN2 and NAN3 was lower than $3.1 \times 10^{3}, 1.1 \times 10^{3}$ and $0.3 \times 10^{3}$ cells $\mathrm{mL}^{-1}$ respectively.

\subsection{Bacterial dynamics}

The average abundance of total bacteria (BA) (Fig 7a) measured in the pond was $3.10 \times 10^{7}$ cells $\mathrm{mL}^{-1}$ (range: $0.76-5.09 \times 10^{7}$ cells $\mathrm{mL}^{-1}$ ). At d 100 a significant decrease in total bacteria abundance was observed from $3.98 \times 10^{7}$ to $0.76 \times 10^{7}$ cells $\mathrm{mL}^{-1}$. This shift was particularly associated with LNA bacterial cells (fig. 7b). After d 100, bacterial concentration increased to 
reach mean values in few days. The abundance of total BA in the inlet channel was generally one order of magnitude lower than in the pond. Fig 7c presents the percentage of HNA bacterial cells during the survey. From d 0 to d 96, the HNA percentage remained constant, with an equilibrium around $47 \%$ of total bacteria. At d 96, HNA relative abundance decreased drastically toward $28 \%$, and reached then $80 \%$ at d 100 . Meanwhile, relative abundance of LNA showed a reversed trend: an increase up to $72 \%$ at d 96 followed by a drastic decline to $20 \%$ at $d 100$. The percentage of HNA in the input water ranged from $22 \%$ to $54 \%$ with an average of $40 \%(\mathrm{~N}=37)$. In the pond, surface and bottom bacterial production (BP) (Fig. 7d) values were comparable, indicating an absence of stratification (results not shown). BP showed 3 peaks at d 54, d 70 and d 107 with 90, 108 and $82 \mu g \mathrm{~L}^{-1} \mathrm{~h}^{-1}$ for each peak, respectively. BP decreased twice at d $60\left(43 \mu \mathrm{g} \mathrm{L} \mathrm{L}^{-1} \mathrm{~h}^{-1}\right)$ and from d 91 and d $96\left(32 \mu \mathrm{g} \mathrm{L} \mathrm{L}^{-1} \mathrm{~h}^{-}\right.$ ${ }^{1}$ ). In the inlet channel, values were lower than in the pond (mean:3.3 $\mu \mathrm{g} \mathrm{L}^{-1} \mathrm{~h}^{-1}$; max: $6.7 \mu \mathrm{g}$ $\left.\mathrm{L}^{-1} \mathrm{~h}^{-1}\right)$

\subsection{Correlation between parameters (Table 1)}

DIN was negatively and highly significantly correlated to picophytoplankton biomass and PEUK abundances. Similarly, DIP was negatively correlated to picophytoplankton biomass, picoeucaryote (PEUK) abundance and bacterial production (BP). Correlation of Si vs. microphytoplankton biomass was also highly significant. Other relationships between BP and environmental parameters were found, such as: picophytoplankton biomass, UNK, SYN, PEUK and HNA abundances. Significant relationships were also determined between total bacteria and picophytoplankton (UNK and PEUK) abundances and biomass. 


\section{Discussion}

\subsection{Phytoplankton compartment}

Total chlorophyll $a$ biomass of the phytoplankton was similar to those reported previously e.g. a Chl a concentrations ranging from 4 to $120 \mu \mathrm{g} \mathrm{L}^{-1}$ in shrimp ponds (Burford, 1997; Yusoff et al., 2002). Chl a concentrations and phytoplankton abundance increased proportionally to the increase of the organic matter input by the shrimp feeding during the survey, as previously reported by several authors (Burford, 1997; Lemonnier and Faninoz, 2006; Cremen et al., 2007). The present study shows that the picophytoplanktonic group was dominant (in terms of cell number and biomass) almost throughout the rearing cycle in the pond. The cell abundance ( $>10^{6}$ cells $\mathrm{mL}^{-1}$ ) found in our survey lay outside the usual ranges for picophytoplankton reported in the literature. In marine ecosystems, picophytoplankton (class size: $0.2-2 \mu \mathrm{m}$ ) comprises photosynthetic prokaryotes, represented primarily by genus Synechococcus and genus Prochlorococcus, which are described as major contributors to biomass and productivity in oligotrophic ecosystems (Partensky et al., 1999), and picoeukaryotic algae, which are less abundant except in coastal waters (Courties et al., 1994; Worden, 2006) and some lagoons (Vaquer et al., 1996; Bec et al., 2005). Previous studies have reported high abundances of Synechococcus sp. in coastal waters (Table 2), although those are usually one order of magnitude lower than the abundances observed during this study. Collos and collaborators reported an exceptional value of $1.1 \times 10^{6}$ cells $\mathrm{mL}^{-1}$ during the summer of 2003 in Thau lagoon (Southern France) (Collos et al., 2009). Our results are consistent with those reported by (Thomas et al., 2010) from aquaculture ponds in New Caledonia and confirm the high abundance of Synechococcus sp. in this ecosystem. However, there are few studies on picophytoplankton and FCM in other aquaculture systems, preventing the detection of significant relationships in similar ecosystems. Our study has confirmed the presence of a new FCM signature among picoplankton with very low red fluorescence and 
light scatter properties related to an undetermined cell type (unpublished data) present at high concentrations $\left(\sim 3 \times 10^{6}\right.$ cells $\left.\mathrm{mL}^{-1}\right)$. The UNK cell type is absent from lagoon waters as well as outside the reef barrier. However, this cell type is sometimes found in low concentration in the inlet channel and at the head of bays, in the near vicinity of discharge waters from shrimp farms (Thomas et al., 2010). In our survey, UNK dominated the picophytoplanktonic fraction ( $5 \times 10^{6}$ cells $\mathrm{mL}^{-1}$ at $\mathrm{d} 74$ ) but disappeared at $\mathrm{d} 91$ when nanophytoplancton blooms occurred (d 96 to d 100). Prochlorococcus sp, a genus of very small $(0.6 \mu \mathrm{m})$ marine cyanobacteria with unusual pigmentation (chlorophyll $b$ ), considered to be the dominant oxygenic phototroph in the tropical and subtropical regions of the world's oceans (Moore et al., 1998), was never observed in the pond or in the input water, although this cyanobacteria was regularly observed in the lagoon seawater. This result suggests that eutrophic pond conditions are not an environment which this cyanobacteria will flourish. Picoeukaryote abundances measured in this study were high (max. $2.6 \times 10^{6}$ cells.mL ${ }^{-1}$ ), lying outside the usual ranges mentioned in the literature (Table 2). Although outnumbered by photosynthetic prokaryotes, picoeukaryotes might contribute significantly to the biomass and primary production in the shrimp pond ecosystem, as already reported in the oceans by ( $\mathrm{Li}, 1994)$. The picophytoplankton dominance in the pond ecosystem could be attributed to the differential responses of phytoplankton as a function of diffusion-limited nutrient acquisition and nitrogen concentrations (Chisholm, 1992). The negative and significant correlation between picophytoplankton biomass and DIN (Table 1) suggests that these small cells were linked to the environment when the DIN concentration was low. The small cell size of picophytoplankton and their intrinsic growth rate may provide a competitive advantage in acquiring nutrients, particularly in environments such as New Caledonian shrimp ponds. After switching on two aerators in pond at d 91, nutrient concentrations (TAN and DIP) increased immediately in the water column (fig. 2) and inversely decreased in the sediment (data not 
shown), suggesting an input to the water column from the sediment. Three to five days later, a significant Chl $a$ peak was measured, matching the nanophytoplankton NAN1 and NAN2 peaks $\left(3 \times 10^{5}\right.$ cells $\left.\mathrm{mL}^{-1}\right)$, when a clear transition between picophytoplankton and nanophytoplankton occurred. Nanophytoplanktonic dominance over the phytoplankton lasted for just a few days. These results suggest that sudden nutrient enrichment stimulates the $>2$ $\mu \mathrm{m}$ fraction growth to the detriment of picophytoplanktonic growth. Concomitantly, the rapid decline of the silicate concentration in the water column indicates that the nanophytoplankton compartment might be dominated by diatoms. The negative and significant correlation between microphytoplankton biomass and this nutrient (Table 1) suggests that microplytoplankton compartment might also be dominated by diatoms, which are regularly identified by optical microscopy in shrimp ponds. The effect of punctual nutrient inputs on phytoplankton dynamic was tested a posteriori with a land-based microcosm (cylindrical fibreglass tanks, $1600 \mathrm{~L}$ ) at similar temperatures (unpublished data). This experiment showed a clear transition between picophytoplankton and nanophytoplankton, which peaked 7 days after enrichment, suggesting that this phytoplankton community shift in our survey was probably a consequence of the nutrient input to the water column.

\subsection{Bacterial compartment}

Bacterial abundance (BA) measured ranged between $0.8 \times 10^{7}$ cells $\mathrm{mL}^{-1}$ to $5.1 \times 10^{7}$ cells $\mathrm{mL}^{-1}$ and was comparable to values reported in the literature for semi-intensive and intensive shrimp ponds, ranging from 0.88 to $2.57 \times 10^{7}$ cells $\mathrm{mL}^{-1}$ (Moriarty, 1986; Allan et al., 1995; Burford et al., 2003b; Lemonnier et al., 2010). However, BA was lower than that observed in extensive shrimp ponds of the Mekong delta (Vietnam), where BA ranged from 0.2 to $27.2 \times 10^{8}$ cells $\mathrm{mL}^{-1}$ (Alongi et al., 1999). Compared to natural system, these values remain high compared to those reported by Torréton et al. (2007) in the New Caledonian lagoon or 
by Andrade et al. (2003) in a tropical eutrophic bay characterized by a significant source of allochtonous dissolved organic carbon (Table 3). Bacterial production (BP) values measured in our pond were also high, reaching $110 \mu \mathrm{g} \mathrm{Cl}^{-1} \mathrm{~h}^{-1}$, a threshold higher than values reported in hypertrophic ecosystems, such as polluted tropical seawaters (Sommaruga and Robarts, 1997; Bouvier et al., 2007) or urbanized area (Torréton et al., 2007). During the first 91 days, bacterial abundance was relatively stable $\left(3 \times 10^{7}\right.$ cells $\left.\mathrm{mL}^{-1}\right)$ and a positive relationship between bacterial production and picophytoplankton abundance was observed (Fig. 8). Significant relationships were also found between total bacteria and picophytoplankton (UNK and PEUK) abundances (Table 1). As stated in the literature (Cole et al., 1988; Ducklow and Carlson, 1992; Bouvy et al., 1998), these relationships could be interpreted as the result of a tight trophic coupling between bacteria and phytoplankton compartments. In coastal sites of New Caledonia, characterized by relatively high inorganic and organic matter concentrations, bacterioplankton and phytoplankton are also considered to be strongly linked (RochelleNewall et al., 2008). Our survey suggests that in eutrophic ponds, picophytoplankton were linked to the bacteria compartment. This phytoplankton can directly supply bacteria with organic carbon through exudation from healthy cells or following lysis of senescent and dead cells. However, in a pond ecosystem, bacterioplankton may use a wide variety of carbon sources from feed or shrimp faeces (Burford and Williams, 2001), which can uncouple bacterial reliance on phytoplankton as their sole carbon source. Such uncoupling may allow bacteria to compete successfully with phytoplankton for limiting nutrients (Cotner et al., 2000). It can explain the significant correlations found in our survey between BP and DIP concentrations (Table 1). When the phytoplankton community shifted from pico to nanophytoplankton (d 96 - d 101), we observed a modification of the linkage between the bacteria and picophytoplankton compartments indicating a change in the functioning of the 
microbial loop (Fig. 8). This period of time was also characterized by an increase in shrimp mortality in the pond.

The separation of types and groups of bacterioplankton - HNA and LNA - was one of the first results obtained by the use of flow cytometry for bacterial nucleic acid content (Li et al., 1995; Marie et al., 1997). In the present study, the relationship between bacterial production (BP) and HNA was significant (Table 1), suggesting that HNA bacteria are the dynamic members of the bacterial assemblage, as previously reported in a similar context (Lemonnier et al., 2010). With regard to those bacteria in our study, their ratio to the total bacterial counts ranged from $28 \%$ to $80 \%$ with an average of $51 \%$. Our results are in the same 15 to $90 \%$ range reported by the literature for field studies (Li et al., 1995; Jellett et al., 1996; Servais et al., 2003). The results obtained on the apparent nucleic acid content indicated an interesting temporal variability on percentage distribution of both bacterial groups. During the first 91 days, the relative abundance of the HNA bacteria fraction was more stable (47\%) ranging from 30 to 54\%. From d 96, HNA relative abundance decreased drastically to $28 \%$, and then increased to approach a value close $(80 \%)$ with the maximum at $\mathrm{d} 100$. This can be explained by the strong decrease of LNA abundance compared to HNA (Fig. 7a and 7b). These changes occurred on a very short time-scale ( 1 to 2 days) and were followed by an increase in the abundance (HNA and LNA) and activity of bacteria. The nucleic acid content of a bacteria cell as differentiated by flow cytometry appears to reflect different causes, which could include phylogenic affiliation or physiological conditions (Scharek and Latasa, 2007). We do not have more specific information about the evolution of the most abundant groups of bacteria at a phylogenetic level. However, we suppose that phytoplankton shift observed in our survey was followed by changes in the bacterial community composition, as has recently been shown by several authors using experimental mesocosms (Riemann et al., 2000; Pinhassi et al., 2004; Teira et al., 2008). 


\section{Conclusion}

As regards zootechnical, pathological and environmental parameters, the results obtained in the present survey were typical of those reported by Mermoud et al. (1998), Goarant et al. (2004), Lefevre et al. (2004) and Lemonnier (2007). In this study, the base of the food chain was composed of very small cells and the microbial loop dominated the column water food web. Conversely, when a significant and sudden import of nutrients took place, the ecosystem shifted from pico to nanophytoplankton, implying a modification of the functioning of the microbial loop. This shift was followed by a significant shrimp mortality outbreak caused by $V$. penaeicida. Interestingly, the pathogen could be detected in the water column and in healthy and moribund shrimp from d 61 (Goarant, pers. com.), without causing significant mortalities. We previously reported that a decrease in the seawater temperature alone was not sufficient to activate the mortality outbreak (Lemonnier, 2007). The results obtained in this study lead us to hypothesise that the environmental shift could be implicated in the occurrence of disease outbreaks. Lemonnier et al. (2010) reported similar results in another vibriosis known as summer syndrome, which affects shrimp aquaculture ponds in New Caledonia. Using flow cytometric analysis and real-time PCR concomitantly to quantify the pathogen (Goarant and Merien, 2006) in epidemiological surveys, we should be able to calculate the effect of each factor (temperature, pathogen, environmental shift) potentially involved in syndrome 93 and improve our knowledge of the significance of environmental conditions on disease emergence in aquaculture ecosystems.

\section{Acknowledgements}

This work was supported by a research grant from the Northern Province, Southern Province and Institut Français de Recherche et d'Exploitation de la Mer (IFREMER). The authors thank all the staff from IFREMER and particularly B. Beliaeff for his help to statistical analyses, D. 
Ansquer, P. Brun, C. Goarant and C. Mugnier and P. Gérard and J-P. Torréton from IRD. We

warmly acknowledge Ian Salter and Y. Labreuche for the improvement of this manuscript.

\section{Literature cited}

Agawin, N.S.R., Duarte, C.M., Agustía, L., McManus, L., 2003. Abundance, biomass and growth rates of Synechococcus sp. in a tropical coastal ecosystem (Philippines, South China Sea). Estuarine, Coastal and Shelf Science 56, 493-502.

Allan, G.L., Moriarty, D.J.W., Maguire, G.B., 1995. Effects of pond preparation and feeding rate on production of Penaeus monodon fabricius, water quality, bacteria and benthos in model farming ponds. Aquaculture 130, 329-349.

Alongi, D.M., Dixon, P., Johnston, D.J., Tien, D.V., Xuan, T.T., 1999. Pelagic processes in extensive shrimp ponds of the Mekong delta, Vietnam. Aquaculture 175, 121-141.

Alonso-Rodriguez, R., Paez-Osuna, F., 2003. Nutrients, phytoplankton and harmful algal blooms in shrimp ponds: a review with special reference to the situation in the Gulf of California. Aquaculture 219, 317-336.

Andrade, L., Gonzalez, A.M., Araujo, F.V., Paranhos, R., 2003. Flow cytometry assessment of bacterioplankton in tropical marine environments. Journal of Microbiological Methods 55, 841-850.

Bec, B., Husseini-Ratrema, J., Collos, Y., Souchu, P., Vaquer, A., 2005. Phytoplankton seasonal dynamics in a Mediterranean coastal lagoon: emphasis on the picoeukaryote community. Journal of Plankton Research 27, 881-894.

Bouvier, T., del Giorgio, P.A., Gasol, J.M., 2007. A comparative study of the cytometric characteristics of High and Low nucleic-acid bacterioplankton cells from different aquatic ecosystems. Environmental Microbiology 9, 2050-2066.

Bouvy, M., Arfi, R., Cecchi, P., Corbin, D., Pagano, M., Saint-Jean, L., Thomas, S., 1998. Trophic coupling between bacterial and phytoplanktonic compartments in shallow tropical reservoirs (Ivory Coast, West Africa). Aquatic Microbial Ecology 15, 25-37.

Briand, E., Pringault, O., Jacquet, S., Torreton, J.-P., 2004. The use of oxygen microprobes to measure bacterial respiration for determining bacterioplankton growth efficiency. Limnology and Oceanography-Methods 2, 406-416.

Burford, M., 1997. Phytoplankton dynamics in shrimp ponds. Aquaculture Research 28, 351360.

Burford, M.A., Costanzo, S.D., Dennison, W.C., Jackson, C.J., Jones, A.B., McKinnon, A.D., Preston, N.P., Trott, L.A., 2003a. A synthesis of dominant ecological processes in intensive shrimp ponds and adjacent coastal environments in NE Australia. Marine Pollution Bulletin 46, 1456-1469.

Burford, M.A., Thompson, P.J., McIntosh, R.P., Bauman, R.H., Pearson, D.C., 2003b. Nutrient and microbial dynamics in high-intensity, zero-exchange shrimp ponds in Belize. Aquaculture 219, 393-411.

Burford, M.A., Williams, K.C., 2001. The fate of nitrogenous waste from shrimp feeding. Aquaculture 198, 79-93.

Calvo-Díaz, A., Anxelu, X., Morán, G., 2008. Seasonality of picophytoplankton chlorophyll a and biomass in the central Cantabrian Sea, southern Bay of Biscay. Journal of Marine Systems 72, 271-281. 
Casé, M., Leca, E.E., Leita, S.N., Sant'Anna, E.E., Schwamborn, R., Travassos de Moraes Junior, A., 2008. Plankton community as an indicator of water quality in tropical shrimp culture ponds. Marine Pollution Bulletin 56, 1343-1352.

Charles, F., Lantoine, F., Brugel, S., Chrétiennot-Dinet, M.-J., Quiroga, I., Rivière, B., 2005. Seasonal survey of the phytoplankton biomass, composition and production in a littoral NW Mediterranean site, with special emphasis on the picoplanktonic contribution. Estuarine, Coastal and Shelf Science 65, 199-212.

Chisholm, S.W., 1992. What Limits Phytoplankton Growth. Oceanus 35, 36-46.

Cloern, J.E., 2001. Our evolving conceptual model of the coastal eutrophication problem. Marine Ecology Progress Series 210, 223-253.

Cole, J.J., Findlay, S., Pace, M.L., 1988. Bacterial production in fresh and saltwater ecosystems: a cross-system overview. Marine Ecology Progress Series 43, 1-10.

Collos, Y., Bec, B., Jauzein, C., Abadie, E., Laugier, T., Lautier, J., Pastoureaud, A., Souchu, P., Vaquer, A., 2009. Oligotrophication and emergence of picocyanobacteria and a toxic dinoflagellate in Thau lagoon, southern France. Journal of Sea Research 61, 68-75.

Costa, R., Mermoud, I., Koblavi, S., Morlet, B., Haffner, P., Berthe, F., Legroumellec, M., Grimont, P., 1998. Isolation and characterization of bacteria associated with Penaeus stylirostris disease (Syndrome 93) in New Caledonia. Aquaculture 164, 297-309.

Cotner, J.B., Bootsma, H., Johengen, T., Cavaletto, J.F., Gardner, W.S., 2000. Nutrient limitation of heterotrophic bacteria in Florida bay. Estuaries 23, 611-620.

Courties C., Vaquer A., Troussellier M., Lautier J., Chrétiennot-Dinet M-J., Neveux J., Machado C., Claustre H. 1994. Smallest eukaryotic organism. Nature 370, 255.

Cremen, M.C.M., Martinez-Goss, M.R., Corre Jr., V.L., Azanza, R.V., 2007. Phytoplankton bloom in commercial shrimp ponds using green-water technology. Journal of Applied Phycology 19, 615-624.

Della Patrona, L., Brun, P., 2008. L'élevage de la crevette bleue en Nouvelle-Calédonie Litopenaeus stylirostris - bases biologiques et zootechnie. Ed. Département LEAD (Laboratoire Ecosystème et Aquaculture Durable) en Nouvelle-Calédonie: 312 p.

Ducklow, H.W., Carlson, C.A., 1992. Oceanic bacterial production. Advances in Microbial Ecology 12, 113-181.

Endo, H., Nakayama, J., Hayashi, T., 2000. Application of flow cytometry to environmental control in marine aquaculture. Materials Science and Engineering: C 12, 83-88.

Fukuda, R., Ogawa, H., Nagata, T., Koike, I., 1998. Direct determination of carbon and nitrogen contents of natural bacterial assemblages in marine environments. Applied and Environmental Microbiology 64, 3352-3358.

Gasol, J.M., Zweifel, U.L., Peters, F., Fuhrman, J.A., Hagström, Å., 1999. Significance of size and Nncleic acid content heterogeneity as measured by flow cytometry in natural planktonic bacteria. Applied and Environmental Microbiology 65, 4475-4483.

Goarant, C., Merien, F., 2006. Quantification of Vibrio penaeicida, the etiological agent of Syndrome 93 in New Caledonian shrimp, by real-time PCR using SYBR Green I chemistry. Journal of Microbiological Methods 67, 27-35.

Goarant, C., Herlin, J., Ansquer, D., Brizard, R., Marteau, A.L., 2004. Vibrio penaeicida et le syndrome 93 dans les fermes de crevettes de Nouvelle-Calédonie: revue et perspectives. Ed. Ifremer, Actes Colloq., 38, In: styli 2003. Trente ans de crevetticulture en NouvelleCalédonie, pp. 203-209.

Goarant, C., Merien, F., Berthe, F., Mermoud, I., Perolat, P., 1999. Arbitrarily primed PCR to type Vibrio spp. pathogenic for shrimp. Applied and Environmental Microbiology 65, $1145-1151$.

Holm-Hansen, O., Lorenzen, C.J., Holmes, R.W., Strickland, J.D.H., 1965. Fluorometric determination of chlorophyll. ICES Journal of Marine Science 30, 3-15. 
Jacquet, S., Delesalle, B., Torréton, J.-P., Blanchot, A., 2006. Responses of the phytoplankton communities to increased anthropogenic influences (Southwestern Lagoon, New Caledonia). Marine Ecology Progress series 320, 65-78.

Jellett, J., Li, W., Dickie, P., Boraie, A., Kepkay, P., 1996. Metabolic activity of bacterioplankton communities assessed by flow cytometry and single carbon substrate utilization. Marine Ecology Progress series 136, 213-225.

Koroleff, F., 1976. Determination of ammonia, in: Grasshof, K. (Ed.), Methods in seawater analysis. Verlag Chemie, Weineim, RFA, pp. 126-133.

Lebaron, P., Servais, P., Agogue, H., Courties, C., Joux, F., 2001a. Does the high nucleic acid content of individual bacterial cells allow us to discriminate between active cells and inactive cells in aquatic systems? Applied and Environmental Microbiology 67, 17751782.

Lebaron, P., Servais, P., Troussellier, M., Courties, C., Muyzer, G., Bernard, L., Schafer, H., Pukall, R., Stackebrandt, E., Guindulain, T., Vives-Rego, J., 2001b. Microbial community dynamics in Mediterranean nutrient-enriched seawater mesocosms: changes in abundances, activity and composition. FEMS Microbiology Ecology 34, 255-266.

Lebaron P., Servais P., Troussellier M., Courties C., Vives-Rego J., Muyzer G., Bernard L., Guindulain T., Schäfer H., Stackerbrandt E., 1999. Changes in bacterial community structure in seawater water mesocosms differing in their nutrient status. Aquatic Microbial Ecology 19, 255-267.

Lefevre, J., Lemonnier, H., Goarant, C., Blanchot, J., 2004. Evolution des paramètres physico-chimiques et biologiques des bassins d'élevage de crevettes soumis à deux régimes de renouvellement en eau avant et pendant des mortalités de type Syndrome 93., In: styli 2003. Trente ans de crevetticulture en Nouvelle-Calédonie, IFREMER ed. Ed. Ifremer, Actes Colloq., 38, pp. 158-166.

Legendre, L., Courties, C., Trousselier, M., 2001. Flow cytometry in oceanography 19891999: Environmental challenges and research trends. Cytometry 44, 164-172.

Lemonnier, H., 2007. Effet des conditions environnementales sur le déclenchement des pathologies à Vibrio dans les élevages de crevettes de Nouvelle-Calédonie. Thèse de Doctorat de l'Université de La Rochelle. Discipline Océanologie Biologique. 203 p.

Lemonnier, H., Courties, C., Mugnier, C., Torréton, J.-P., Herbland, A., 2010. Nutrient and microbial dynamics in eutrophying shrimp ponds affected or unaffected by vibriosis. Marine Pollution Bulletin 60, 402-411.

Lemonnier, H., Faninoz, S., 2006. Effect of water exchange on effluent and sediment characteristics and on partial nitrogen budget in semi-intensive shrimp ponds in New Caledonia. Aquaculture Research 37, 938-948.

Li, W.K.W., 2009. From cytometry to macroecology: a quarter century quest in microbial oceanography. Aquatic Microbial Ecology 57, 239-251.

Li, W.K.W., Dickie, P.M., 2001. Monitoring phytoplankton, bacterioplankton, and virioplankton in a coastal inlet (Bedford Basin) by flow cytometry. Cytometry 44, 236246.

Li, W.K.W., Jellett, J.F., Dickie, P.M., 1995. DNA Distributions in planktonic bacteria stained with TOTO or TO-PRO. Limnology and Oceanography 40, 1485-1495.

Li, W.K.W., 1994. Primary production of Prochlorophytes, Cyanobacteria, and eucaryotic ultraphytoplankton: measurements from flow cytometric sorting. Limnology and Oceanography 39, 169-175.

Liu, H., Chang, J., Tseng, C.-M., Wen, L.-S., Liu, K.K., 2007. Seasonal variability of picoplankton in the Northern South China Sea at the SEATS station. Deep-Sea Research II 54, 1602-1616. 
Liu, H., Dagg, M., Campbell, L., Urban-Rich, J., 2004. Picophytoplankton and bacterioplankton in the Mississippi River plume and its adjacent waters. Estuaries 27, 147-156.

Marie, D., Partensky, F., Jacquet, S., Vaulot, D., 1997. Enumeration and cell cycle analysis of natural populations of marine picoplankton by flow cytometry using the nucleic acid stain SYBR Green I. Applied and Environmental Microbiology 63, 186-193.

Mermoud, I., Costa, R., Ferré, O., Goarant, C., Haffner, P., 1998. "Syndrome 93" in New Caledonia outdoor rearing ponds of Penaeus stylirostris: history and description of three major outbreaks. Aquaculture 164, 323-335.

Moore, L.R., Rocap, G., Chisholm, S.W., 1998. Physiology and molecular phylogeny of coexisting Prochlorococcus ecotypes. Nature 393, 464-467.

Morán, X.A.G., Bode, A., Suárez, L.A., Nogueira, E., 2007. Assessing the relevance of nucleic acid content as an indicator of marine bacterial activity. Aquatic Microbial Ecology 46, 141-142.

Moriarty, D.J.W., 1997. The role of microorganisms in aquaculture ponds. Aquaculture 151, 333-349.

Moriarty, D.J.W., 1986. Bacterial productivity in ponds used for culture of penaeid prawns. Microbial Ecology 12, 259-269.

Mullin, J.B., Riley, J.P., 1955. The spectrophotometric determination of silicate-silicon in natural waters with special reference to sea water. Analytica Chimica Acta 12, 162-170.

Murphy, J., Riley, J.P., 1962. A modified single solution method for determination of phosphate in natural waters. Analytica Chimica Acta 26, 31-36.

Partensky, F., Hess, W.R., Vaulot, D., 1999. Prochlorococcus, a Marine Photosynthetic Prokaryote of Global Significance. Microbiology and Molecular Biology Reviews 63, 106-127.

Pinhassi, J., Montserrat Sala, M., Havskum, H., Peters, F., Guadayol, O., Malits, A., Marrasé, C., 2004. Changes in bacterioplankton composition under different phytoplankton regimens. Applied and Environmental Microbiology 70, 6753-6766.

Raimbault, P., Slawyk, G., Coste, B., Fry, J., 1990. Feasibility of using an automated colorimetric procedure for the determination of seawater nitrate in the 0 to $100 \mathrm{Nm}$ range Examples from field and culture. Marine Biology 104, 347-351.

Riemann, L., Steward, G.F., Azam, F., 2000. Dynamics of bacterial community composition and activity during a mesocosm diatom bloom. Applied and Environmental Microbiology 66, 578-587.

Rochelle-Newall, E.J., Torréton, J.-P., Mari, X., Pringault, O., 2008. Phytoplanktonbacterioplankton coupling in a subtropical South Pacific coral reef lagoon. Aquatic Microbial Ecology 50, 221-229.

Saulnier, D., Haffner, P., Goarant, C., Levy, P., Ansquer, D., 2000. Experimental infection models for shrimp vibriosis studies: a review. Aquaculture 191, 133-144.

Schäfer H., Bernard L., Courties C., Lebaron P., Servais P., Pukall R., Stackerbrandt E., Troussellier M., Guindulain T., Vives-Rego J., Muyzer G. 2001. Microbial community dynamics in Mediterranean sea nutrient-enriched seawater mesocosms: changes in the genetic diversity of bacterial populations. FEMS Microbial Ecology 34, 243-253.

Scharek, R., Latasa, M., 2007. Growth, grazing and carbon flux of high and low nucleic acid bacteria differ in surface and deep chlorophyll maximum layers in the NW Mediterranean Sea. Aquatic Microbial Ecology 46, 153-161.

Servais, P., Casamayor, E.O., Courties, C., Catala, P., Parthuisot, N., Lebaron, P., 2003. Activity and diversity of bacterial cells with high and low nucleic acid content. Aquatic Microbial Ecology 33, 41-51. 
Smith, D.C., Azam, F., 1992. A simple, economical method for measuring bacterial protein synthesis rates in seawater using 3H-leucine. Marine Microbial Food Webs 6, 104-114.

Sommaruga, R., Robarts, R.D., 1997. The significance of autotrophic and heterotrophic picoplankton in hypertrophic ecosystems. FEMS Microbiology Ecology 24, 187-200.

Teira, E., Gasol, J.M., Aranguren-Gassis, M., Fernández, A., González, J., Lekunberri, I., Álvarez-Salgado, X.A., 2008. Linkages between bacterioplankton community composition, heterotrophic carbon cycling and environmental conditions in a highly dynamic coastal ecosystem. Environmental Microbiology 10, 906-917.

Thomas, Y., Courties, C., El Helwe, Y., Herbland, A., Lemonnier, H., 2010. Spatial and temporal extension of eutrophication associated with shrimp farm wastewater discharges in the New Caledonian Lagoon. Marine Pollution Bulletin 61, 387-398.

Torréton, J.-P., Rochelle-Newall, E., Jouon, A., Faure, V., Jacquet, S., Douillet, P., 2007. Correspondence between the distribution of hydrodynamic time parameters and the distribution of biological and chemical variables in a semi-enclosed coral reef lagoon. Estuarine, Coastal and Shelf Science 74, 766-776.

Troussellier, M., Courties, C., Zettelmaier, S., 1995. Flow cytometric analysis of coastal lagoon bacterioplankton and picophytoplankton: fixation and storage effects. Estuarine, Coastal and Shelf Science 40, 621-633.

Troussellier, M., Courties C., Vaquer A. 1993. Recent applications of flow cytometry in aquatic microbial ecology. Biology of the Cell 78, 111-121.

Vaquer, A., Trousselier, M., Courties, C., Bibent, B., 1996. Standing stock and dynamics of picophytoplankton in the Thau Lagoon (nortwest Mediterranean coast). Limnology and Oceanography 41, 1821-1828.

Vaulot, D., Courties, C., Partensky, F., 1989. A simple method to preserve oceanic phytoplankton for flow cytometric analyses. Cytometry 10, 629-635.

Worden, A.Z., 2006. Picoeukaryote diversity in coastal waters of the Pacific Ocean. Aquatic Microbial Ecology 43, 165-175.

Worden, A.Z., Nolan, J.K., Palenik, B., 2004. Assessing the dynamics and ecology of marine picophytoplankton: The importance of the eukaryotic component. Limnology and Oceanography 49, 168-179.

Yusoff, F.M., Zubaidah, M.S., Matias, H.B., Kwan, T.S., 2002. Phytoplankton succession in intensive marine shrimp culture pond treated with a commercial bacterial product. Aquaculture Research 33, 269-278.

Zimba, P.V., Camus, A., Allen, E.H., Burkholder, J.M., 2006. Co-occurrence of white shrimp, Litopenaeus vannamei, mortalities and microcystin toxin in a southeastern USA shrimp facility. Aquaculture 261, 1048-1055. 
Table 1: Linear correlation coefficients performed using permutation tests (r) between temperature, nutrient (DIN: dissolved inorganic nitrogen; DIP: dissolved inorganic phosphorus; Si: silicates) and phytoplanktonic (UNK: unknown cells, SYN: Synechococcus sp., PEUK: Picoeukaryotes, Total NAN: total nanophytoplankton) and bacterial parameters (HNA: high nucleic acid content bacteria abundance; LNA low nucleic acid content bacteria abundance) in the water column of the pond at $07 \mathrm{~h} 00\left(* * \mathrm{p}<0.01,{ }^{*} \mathrm{p}<0.05\right)$. Only the significant values are reported.

\begin{tabular}{|c|c|c|c|c|c|c|c|c|c|c|c|c|c|c|}
\hline & & & \multicolumn{8}{|c|}{ Phytoplanktonic compartment } & \multicolumn{4}{|c|}{ Bacterial compartment } \\
\hline & & & \multicolumn{4}{|c|}{ Biomass } & \multicolumn{4}{|c|}{ Abundance } & \multicolumn{3}{|c|}{ Abundance } & \multirow[t]{2}{*}{ Production } \\
\hline & & & Total & $<2 \mu$ & $2-20 \mu$ & $>20 \mu$ & UNK & SYN & PEUK & Total NAN & Total & HNA & LNA & \\
\hline \multirow{4}{*}{ 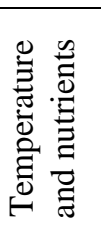 } & $\mathrm{T}$ & & $-0.70 * *$ & & & & & & & & & & & \\
\hline & DIN & & & $-0.80 * *$ & & & $-0.61^{*}$ & & $-0.68 * *$ & & & & & \\
\hline & DIP & & & $-0.73^{*}$ & & & & & $-0.60 *$ & $0.51 *$ & & & & $-0.85 *$ \\
\hline & $\mathrm{Si}$ & & & & & $-0.55^{* *}$ & & & & & & & & \\
\hline \multirow{8}{*}{ 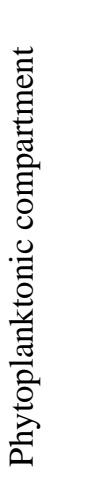 } & & Total & & & & & & & & & & & & \\
\hline & $y$ & $<2 \mu$ & & & & & & & & & & & & \\
\hline & .ี & $2-20 \mu$ & $0.88 * *$ & & & & & & & & & & & \\
\hline & & $>20 \mu$ & $0.62 *$ & & $0.62 *$ & & & & & & & & & \\
\hline & & UNK & & $0.86 * *$ & & & & & & & & & & \\
\hline & $\underset{\Xi}{\tilde{\sigma}}$ & SYN & & & & & $0.64 * *$ & & & & & & & \\
\hline & $\Xi$ & PEUK & & $0.86^{* *}$ & & & $0.98 * *$ & $0.76^{* *}$ & & & & & & \\
\hline & $\ll$ & Total NAN & & & $0.67^{*}$ & & & & & & & & & \\
\hline \multirow{4}{*}{ 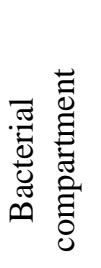 } & 8 & Total & & $0.66^{*}$ & $-0.58 *$ & & $0.55^{*}$ & & $0.63^{* *}$ & & & & & \\
\hline & 胥 & HNA & & $0.79 * *$ & & & $0.66^{*}$ & & $0.72 * *$ & & $0.86^{* *}$ & & & \\
\hline & $\stackrel{\overrightarrow{0}}{\mathbb{Z}}$ & LNA & & & $-0.61^{*}$ & & & & & $-0.43^{*}$ & $0.92 * *$ & $0.62 *$ & & \\
\hline & Production & & & $0.91 * *$ & & & $0.90^{* *}$ & $0.74 *$ & $0.88 * *$ & $-0.77^{*}$ & & $0.86^{*}$ & & \\
\hline
\end{tabular}


Table 2: Maximum Synechococcus sp. (SYN) and picoeukaryotes (PEUK) cell densities from different geographical locations. Data are ranked following decreasing abundance values.

\begin{tabular}{|c|c|c|c|c|}
\hline Site & Ecosystem & Type & cell $\mathrm{mL}^{-1}$ & References \\
\hline New Caledonia & $\begin{array}{l}\text { Experimental } \\
\text { ponds }\end{array}$ & $S Y N$ & $6.3 \times 10^{6}$ & (Lefevre et al., 2004) \\
\hline New Caledonia & pond & $S Y N$ & $3.4 \times 10^{6}$ & This study \\
\hline New Caledonia & ponds & SYN & $2.5 \times 10^{6}$ & $\begin{array}{l}\text { (Thomas et al., in } \\
\text { press) }\end{array}$ \\
\hline Thau (France) & lagoon & $S Y N$ & $1.1 \times 10^{6}$ & (Collos et al., 2009) \\
\hline Bedford basin & Coastal & SYN & $4.0 \times 10^{5}$ & (Li and Dickie, 2001) \\
\hline Mississippi river plume & Coastal & $S Y N$ & $3.3 \times 10^{5}$ & (Liu et al., 2004) \\
\hline Cantabrian Sea & Continental shelf & $S Y N$ & $2.4 \times 10^{5}$ & $\begin{array}{l}\text { (Calvo-Díaz et al., } \\
\text { 2008) }\end{array}$ \\
\hline New Caledonia & lagoon & $S Y N$ & $1.3 \times 10^{5}$ & (Jacquet et al., 2006) \\
\hline Southern California bight & Coastal & $S Y N$ & $1.0 \times 10^{5}$ & (Worden et al., 2004) \\
\hline Thau (France) & lagoon & $S Y N$ & $1.0 \times 10^{5}$ & (Vaquer et al., 1996) \\
\hline South China Sea & Coastal & $S Y N$ & $8.0 \times 10^{4}$ & (Liu et al., 2007) \\
\hline South China Sea & Coastal & $S Y N$ & $2.1 \times 10^{4}$ & (Agawin et al., 2003) \\
\hline Mediterranean & Shallow bay & $S Y N$ & $1.5 \times 10^{4}$ & (Charles et al., 2005) \\
\hline New Caledonia & ponds & PEUK & $3.5 \times 10^{6}$ & $\begin{array}{l}\text { (Thomas et al., In } \\
\text { press) }\end{array}$ \\
\hline New Caledonia & pond & PEUK & $2.6 \times 10^{6}$ & This study \\
\hline Thau (France) & lagoon & PEUK & $2.6 \times 10^{5}$ & (Vaquer et al., 1996) \\
\hline Southern California bight & Coastal & PEUK & $3.0 \times 10^{4}$ & (Worden et al., 2004) \\
\hline Mediterranean & Shallow bay & PEUK & $2.2 \times 10^{4}$ & (Charles et al., 2005) \\
\hline New Caledonia & lagoon & PEUK & $2.0 \times 10^{4}$ & (Jacquet et al., 2006) \\
\hline South China Sea & Coastal & PEUK & $1.5 \times 10^{4}$ & (Liu et al., 2007) \\
\hline Cantabrian Sea & Continental shelf & PEUK & $1.0 \times 10^{4}$ & $\begin{array}{l}\text { (Calvo-Díaz et al., } \\
\text { 2008) }\end{array}$ \\
\hline
\end{tabular}


Table 3: Comparison ranges of bacterial abundance (BA) and production (BP) in the pond with some other environments

\begin{tabular}{|c|c|c|c|c|}
\hline Site & Ecosystem & $\begin{array}{l}\text { BA } \\
\text { (cells ml }^{-1} \text { ) }\end{array}$ & $\begin{array}{l}\mathrm{BP} \\
\left(\mu g \mathrm{Cl}^{-1} \mathrm{~h}^{-1}\right)\end{array}$ & References \\
\hline New Caledonia & $\begin{array}{l}\text { Intensive shrimp } \\
\text { ponds }\end{array}$ & $1.8-6.0 \times 10^{7}$ & $18-130$ & (Lemonnier et al., 2010) \\
\hline New Caledonia & $\begin{array}{l}\text { Semi-intensive } \\
\text { shrimp pond }\end{array}$ & $0.8-5.1 \times 10^{7}$ & $32-108$ & This study \\
\hline Belize & $\begin{array}{l}\text { Super-intensive } \\
\text { shrimp ponds }\end{array}$ & $3.4-5.4 \times 10^{7}$ & - & (Burford et al., 2003b) \\
\hline Malaysia & $\begin{array}{l}\text { Semi-intensive } \\
\text { shrimp ponds }\end{array}$ & $0.8-2.6 \times 10^{7}$ & $17.9-87.5$ & (Moriarty, 1986) \\
\hline Australia & $\begin{array}{l}\text { Shrimp } \\
\text { mesocosms }\end{array}$ & $2.3-8.8 \times 10^{6}$ & $0.9-13.7$ & (Allan et al., 1995) \\
\hline $\begin{array}{l}\text { Mekong delta } \\
\text { (Vietnam) }\end{array}$ & $\begin{array}{l}\text { Extensive shrimp } \\
\text { ponds }\end{array}$ & $2-272 \times 10^{7}$ & $0.1-12.4$ & (Alongi et al., 1999) \\
\hline New Caledonia & $\begin{array}{l}\text { farm input } \\
\text { seawater }\end{array}$ & $0.3-5.3 \times 10^{6}$ & $1.0-6.7$ & This study \\
\hline Brazil & $\begin{array}{l}\text { Tropical eutrophic } \\
\text { bay }\end{array}$ & $1.0-6.9 \times 10^{6}$ & $2.0-7.4$ & (Andrade et al., 2003) \\
\hline New Caledonia & lagoon & $0.4-1.5 \times 10^{6}$ & $0.02-2.86$ & (Torréton et al., 2007) \\
\hline Brazil & $\begin{array}{l}\text { Oligotrophic } \\
\text { ocean }\end{array}$ & $0.4-5.5 \times 10^{5}$ & $0.0-0.1$ & (Andrade et al., 2003) \\
\hline
\end{tabular}




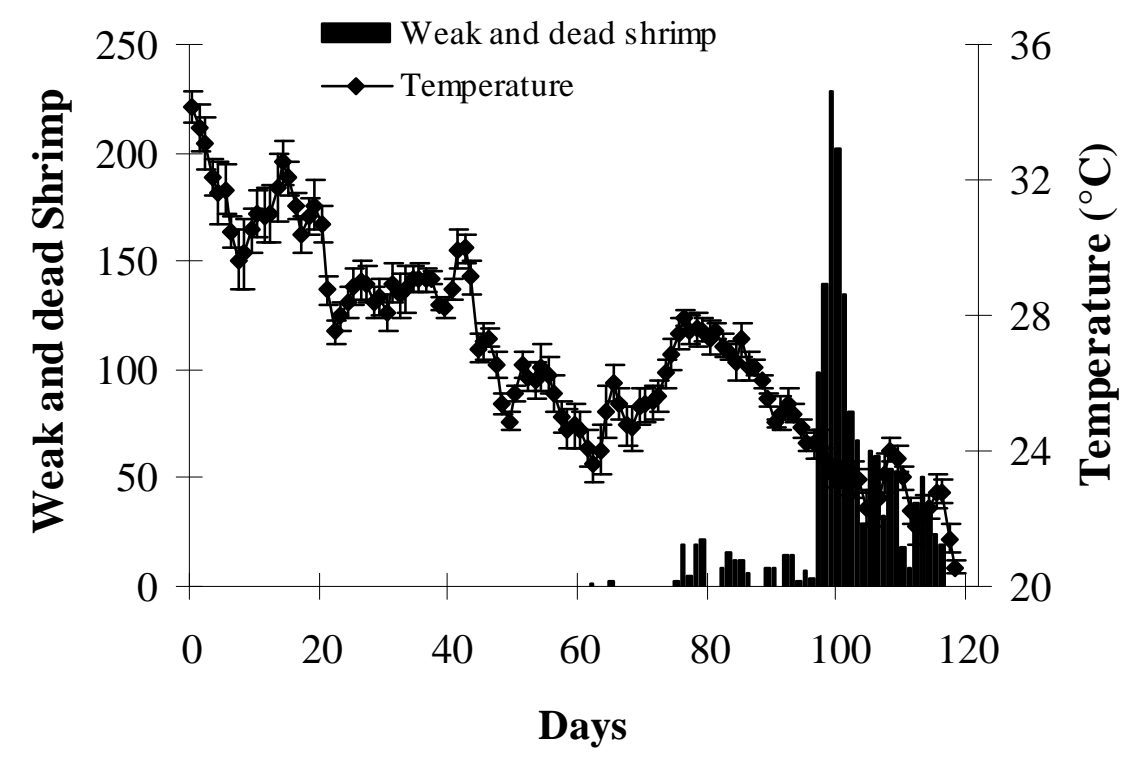

Fig. 1: Daily average temperature in the pond (line) (from three stations, and 2 depths) and, daily weak and dead shrimp count on the pond edges (bars). Error bars correspond to the standard deviation ( $\sigma$, from 6 measurements (surface and bottom samples of the 3 stations)). 


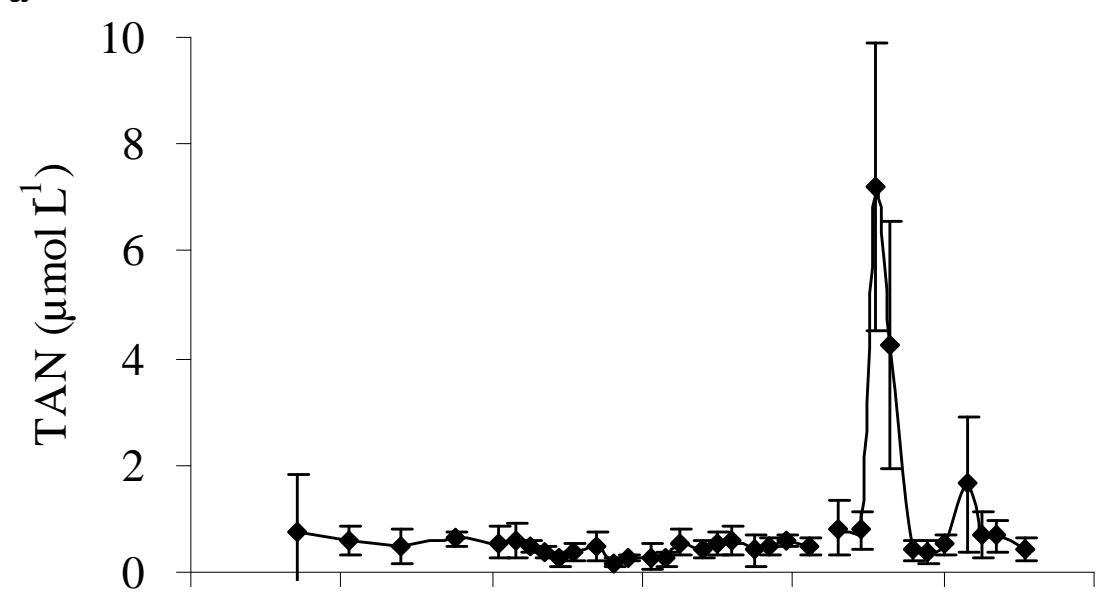

b

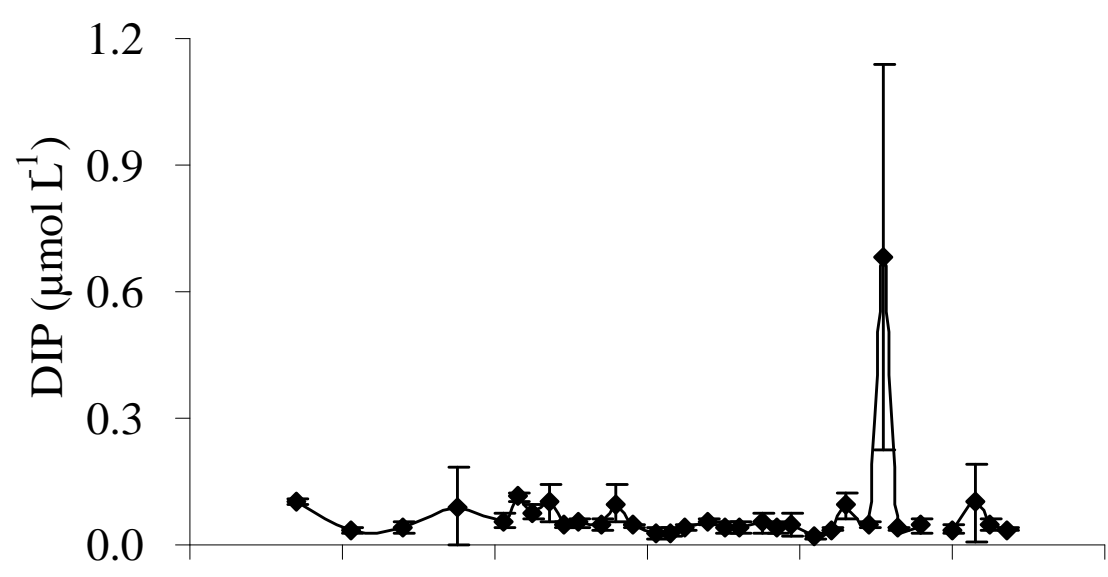

C

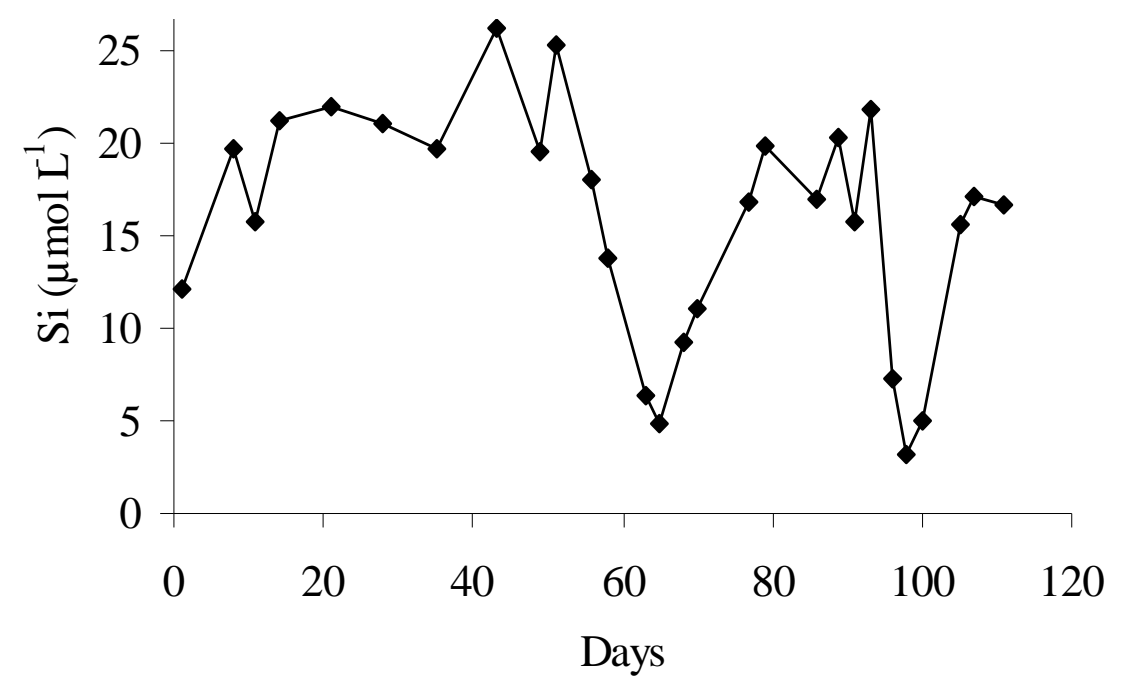

Fig. 2: Temporal variations of daily averaged total ammonia nitrogen (TAN) (a) and dissolved inorganic phosphorus (DIP) (b) (from the three stations, and 2 depths at $7 \mathrm{~h} 00$ and $16 \mathrm{~h} 00, \mathrm{~N}=$ 12) and silicates ( $\mathrm{Si}$ ) (c) (from one station and one depth at 7h00) concentrations in the pond. Error bars correspond to the standard deviation. 


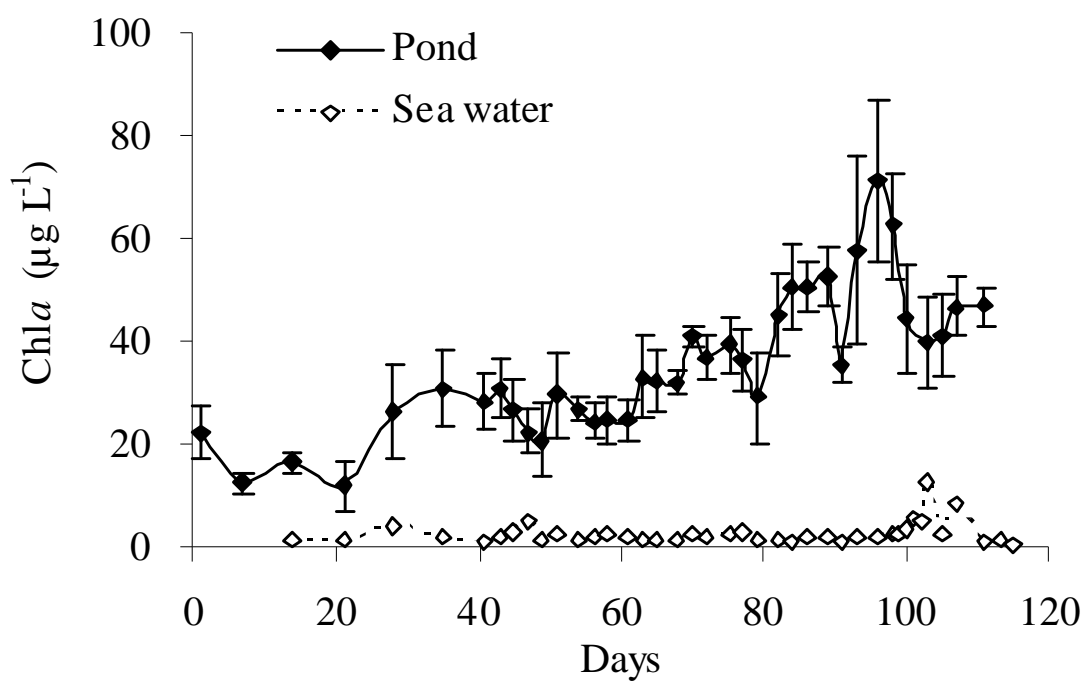

Fig. 3: Temporal variations of daily averaged Chlorophyll $a$ concentrations (Chl $a$ ) in pond water (from the three stations, and 2 depths, at $06 \mathrm{~h} 00$ and $16 \mathrm{~h} 00, \mathrm{~N}=12$ ) and in the input water $(\mathrm{N}=1)$. Error bars correspond to the standard deviation. 


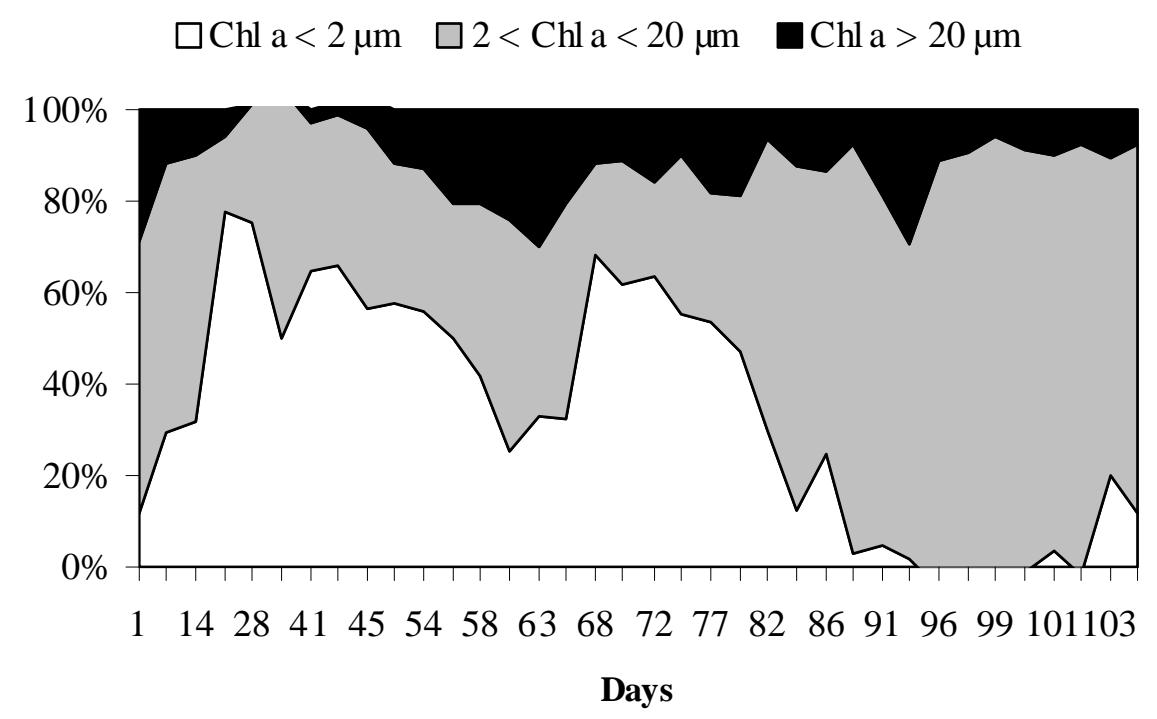

Fig. 4. Temporal variations of the chlorophyll $a$ (Chl $a$ ) fractionated biomass in the pond (from one station, and 2 depths, $\mathrm{N}=2$ ). 


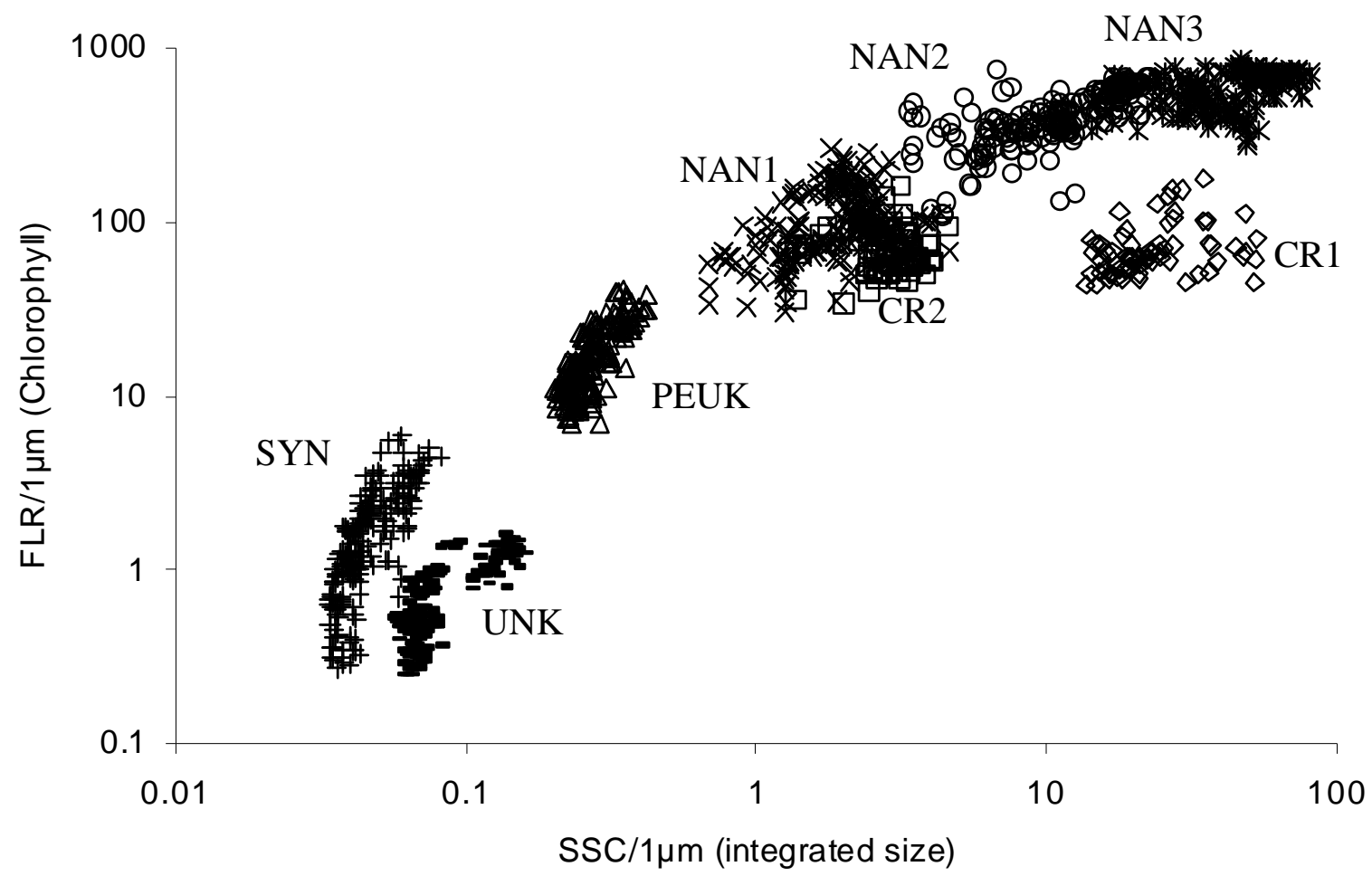

Fig. 5. Normalized cell characteristics from pond samples on a SSC/FLR dot plot to characterize the various cell types measured by FCM (CR1, CR2: Cryptophytes 1 and 2; NAN1, NAN2, NAN3: Nanophytoplankton 1, 2 and 3; PEUK: Picoeukaryotes; SYN: Synechococcus sp., UNK: unknown cells). 
$\mathrm{a}$

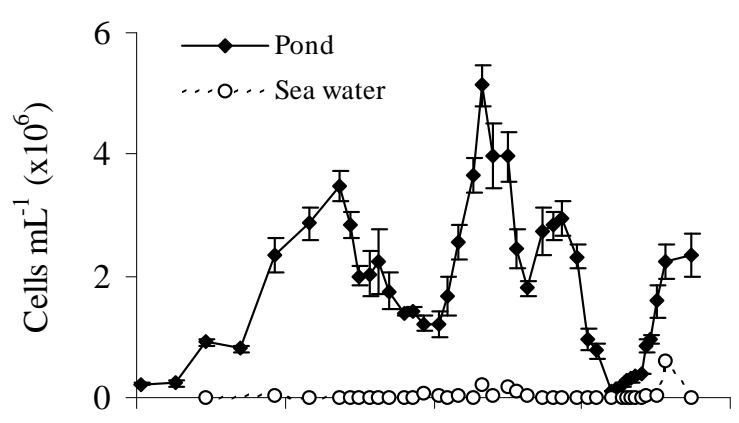

C

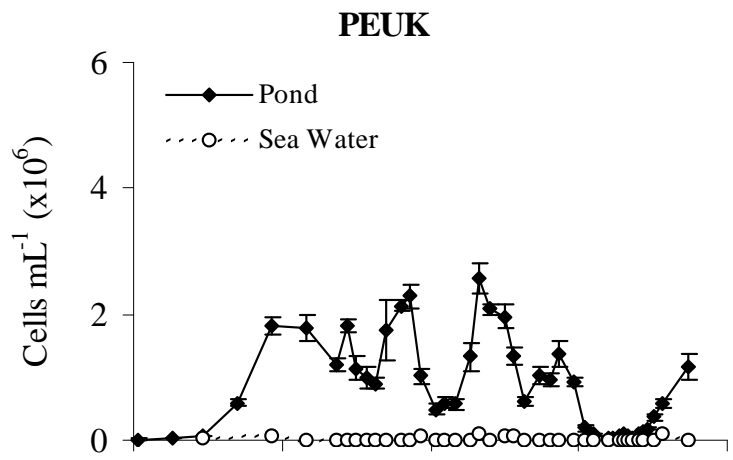

e

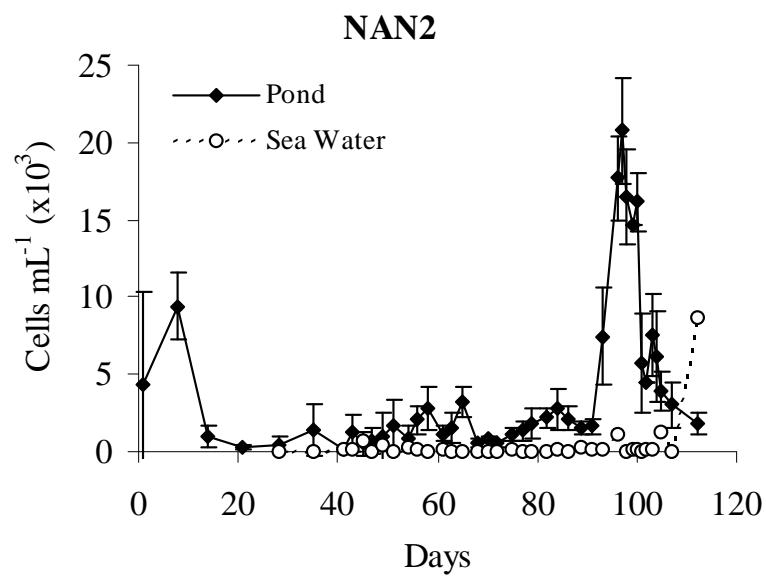

$\mathrm{b}$

SYN

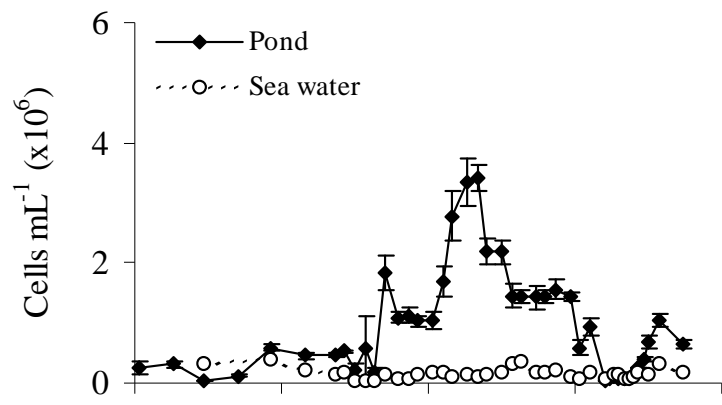

d

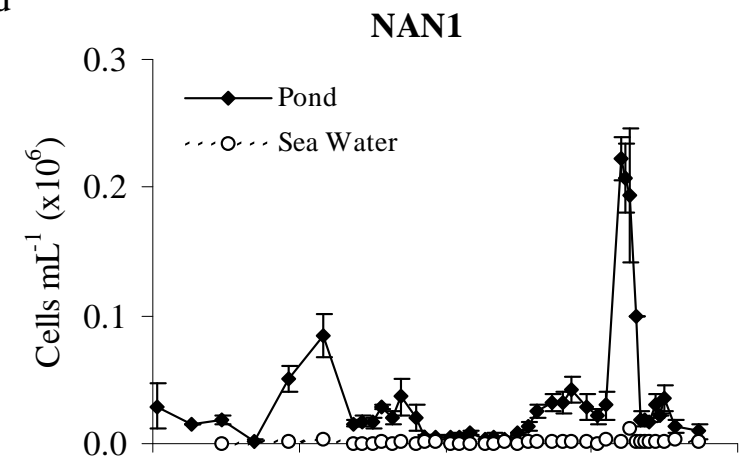

$\mathrm{f}$

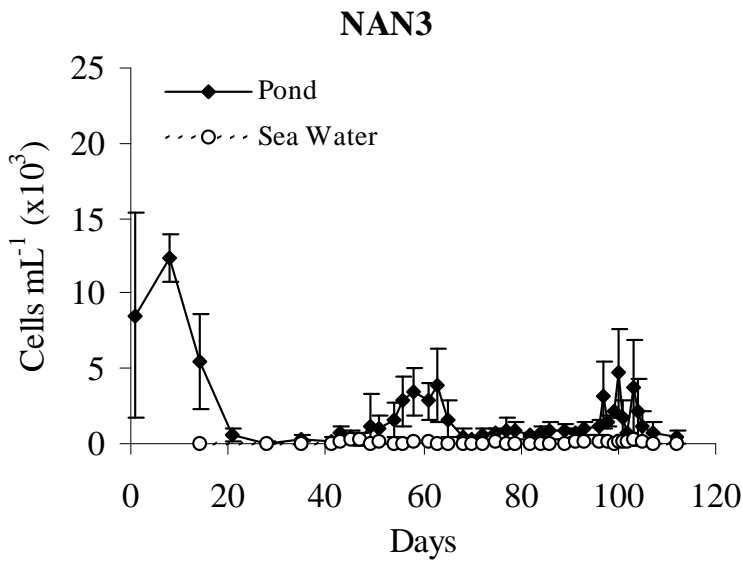

Fig. 6. Temporal variations of picophytoplankton (UNK: unknown cells, SYN: Synechococcus sp., PEUK: Picoeukaryotes) and nanophytoplankton (NAN1, NAN2, NAN3: Nanophytoplankton 1, 2 and 3) in the pond (from the three stations, and 2 depths, $N=6$ ) and in the input water $(\mathrm{N}=1)$. Error bars correspond to the standard deviation. Abundances are represented in thousand or millions of cells per $\mathrm{mL}$. 
a

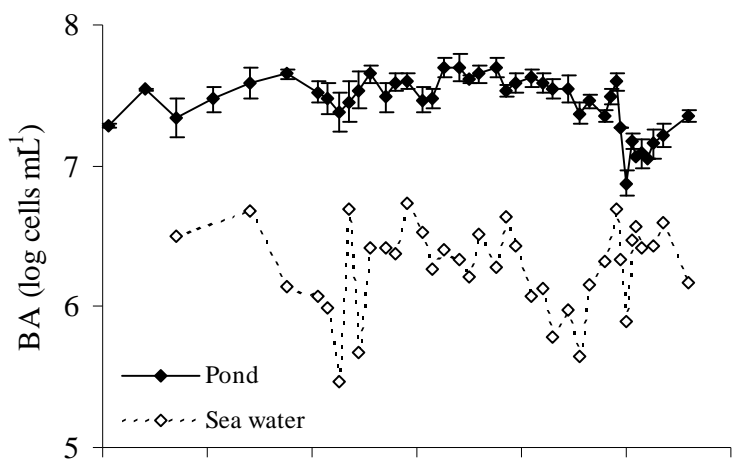

C

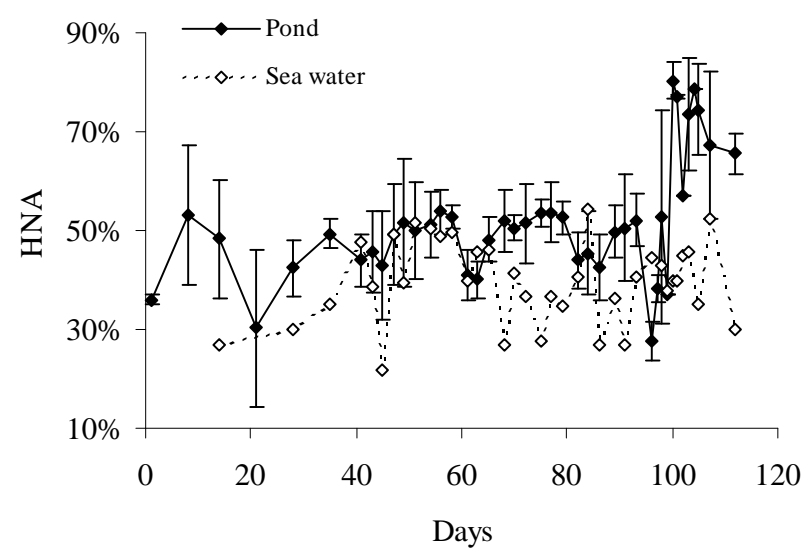

$\mathrm{b}$
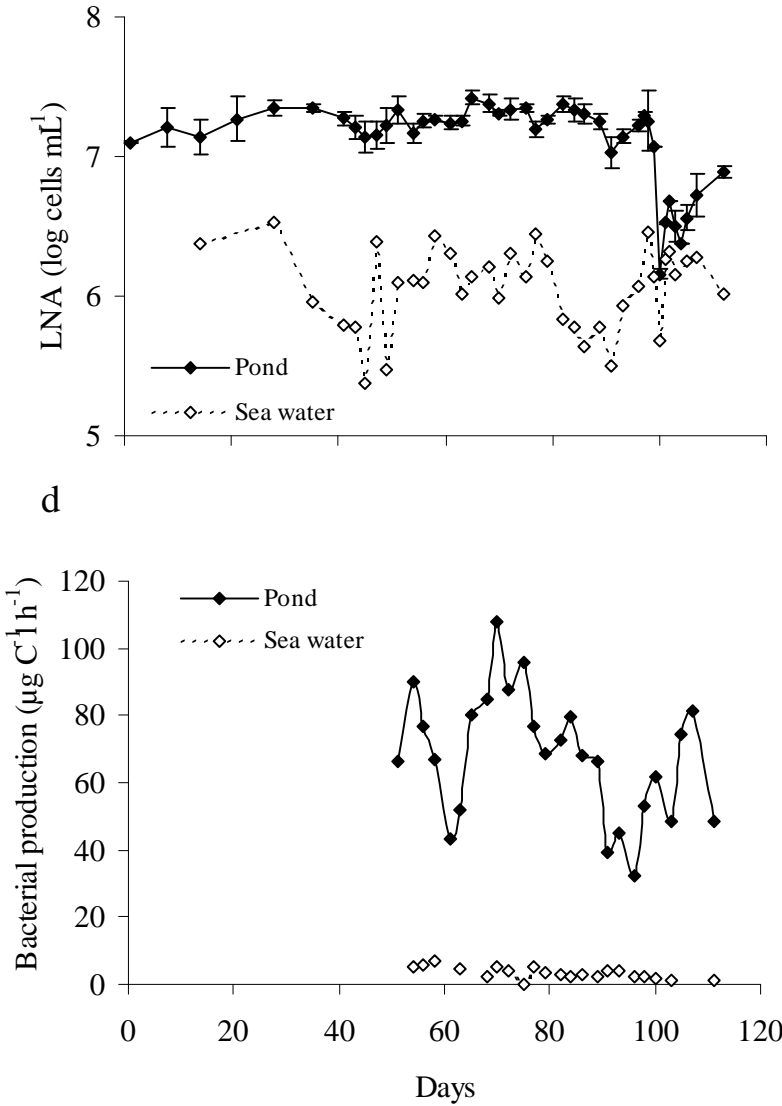

Fig. 7. Distribution of (a) total bacterial abundance (BA) and (b) LNA abundance (c) HNA abundance ratio in the pond (from the three stations, and 2 depths, $\mathrm{N}=6$ ) and in the input water $(\mathrm{N}=1)$. Error bars correspond to the standard deviation. (d) Mean bacterial production $(\mathrm{N}=2)$ measured in surface and near the bottom at one station in the pond and in the input water. (HNA: high nucleic acid content; LNA low nucleic acid content). 


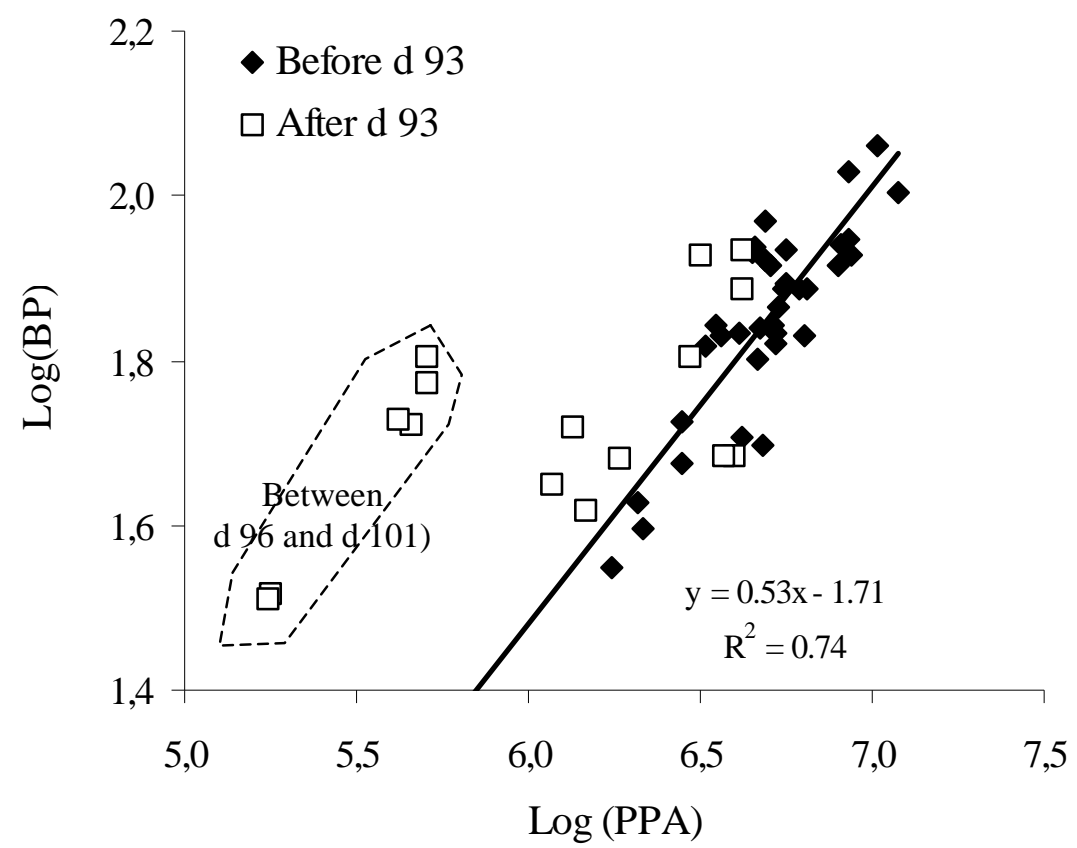

Fig. 8. Relationship between picophytoplankton abundance (PPA) and bacterial production (PB) during the survey. Data collected after d 93 were excluded to calculate the correlation coefficient and draw the correlation line. 